\title{
The Delian Maidens and their relevance to choral mimesis in classical drama
}

\section{Citation}

Nagy, Gregory. 2013. The Delian Maidens and their Relevance to Choral Mimesis in Classical Drama. In Choral Mediations in Greek Tragedy, ed. R. Gagné and M. G. Hopman, 227-256. Cambridge: Cambridge University Press.

\section{Published Version}

doi:10.1017/CB09781139519564.010

\section{Permanent link}

http://nrs.harvard.edu/urn-3:HUL.InstRepos:15549847

\section{Terms of Use}

This article was downloaded from Harvard University's DASH repository, and is made available under the terms and conditions applicable to Other Posted Material, as set forth at http:// nrs.harvard.edu/urn-3:HUL.InstRepos:dash.current.terms-of-use\#LAA

\section{Share Your Story}

The Harvard community has made this article openly available.

Please share how this access benefits you. Submit a story.

\section{Accessibility}




\section{The Delian Maidens and their Relevance to Choral Mimesis in Classical Drama}

\section{Gregory Nagy}

[Originally published as Chapter 10 in Choral Mediations in Greek Tragedy, ed. R. Gagné and M. G. Hopman (Cambridge: Cambridge University Press, 2013), 227-256. In this online version, the original page-numbers of the printed version are indicated within braces ("\{" and "\}"). For example, "\{227|228\}" indicates where p. 227 of the printed version ends and p. 228 begins.]

\section{Introduction}

My focus is on the Delian Maidens, as represented in the Homeric Hymn (3) to Apollo. These maidens, in verse 163 of the Hymn, are said to be engaging in an act of mimēsis 'reenactment' (hereafter written simply as mimesis), as expressed in this verse by the verb mimeîsthai 'reenact, imitate', derived from the noun mimos 'mime'. I will argue that the act of mimesis as represented in this archaic hymn is related to the act of mimesis as performed by choruses in classical drama-specifically, in the composite dramatic genres of tragedy, comedy, and the satyr play. ${ }^{1}$ In terms of my argument, the mimesis performed by the Delian Maidens in the Hymn is a model for understanding how the classical genres of drama assimilated various archaic genres of choral songmaking. As we will see, this model comes to life in the interaction of solo and choral performance as represented in the Hymn. Such an interaction, as we will also see, is an act of mediation that proves to be the essence of mimesis in classical drama.

\footnotetext{
${ }^{1}$ I mention here only three of the four genres of classical Athenian drama. That is because the fourth genre, the dithyramb, is unlike tragedy, comedy, and the satyr play by virtue of the fact that it is entirely choral. By contrast, the other three genres are composite by virtue of the fact that they are composed of non-choral parts performed by professional actors as well as choral parts performed by the nonprofessional chorus. As my argumentation proceeds, I will elaborate on the distinction I make here between the professionalized actors and the nonprofessional chorus.
} 
My overall argumentation stems primarily from the book Pindar's Homer (1990). In that work, I confronted two relevant questions: who are the Delian Maidens and what do they have to do with mimesis? My findings focused on the identity of the Maidens as a chorus, and on the essence of mimesis as a mental activity performed by a chorus. A summary of these findings was later published as the article "Transformations of Choral Lyric" by the journal Arion (1994/1995), in an issue dedicated to the topic of choral performance. ${ }^{3}$ I then expanded on these findings in the book Poetry as $\{227 \mid 228\}$ Performance (1996). Here I will reassess this earlier work in the light of later work done by myself and by others. In the case of work done by others, I highlight the articles of Albert Henrichs (1996) and Anastasia Erasmia Peponi (2009); also the book of Barbara Kowalzig (2007). In the case of my own later work, I highlight two books, Homer the Classic (2008/2009) and Homer the Preclassic (2009/2010). ${ }^{5}$

When I use the word chorus here, I have in mind the Greek word khoros. I understand the fundamental meaning of khoros to be 'song-and-dance group', with emphasis on both song and dance, although I also understand that either the song may dominate the dance or the dance may dominate the song in different choral traditions. ${ }^{6}$

When I use the word mimesis, I understand the primary meaning of the original Greek word to be 'reenactment', as in a chorus. What I mean by a reenactment is a reliving through ritual. And I understand the secondary meaning of mimesis to be 'imitation'. I say secondary because I understand imitation to be a built-in aspect of reenactment. All reenactment is imitation, but not all imitation is reenactment. I say that all reenactment is imitation because

\footnotetext{
${ }^{2}$ Nagy 1990a, hereafter abbreviated as PH. This and other abbreviations are listed in the Bibliography.

${ }^{3}$ Nagy 1994/1995b, hereafter abbreviated as TCL.

${ }^{4}$ Nagy 1996a, hereafter abbreviated as PP.

${ }^{5}$ Nagy 2009 (preceded by an online version in 2008) and Nagy 2010 (preceded by an online version in 2009) are hereafter abbreviated as $H C$ and $H P C$ respectively.

${ }^{6}$ TCL 41 .
} 
the one who relives something through ritual can imitate predecessors who have already relived that something through ritual. And I say that not all imitation is reenactment because you can imitate someone or something without having to relive anything through ritual. Gradually, starting in the fifth century BCE, the primary meaning of mimesis as 'reenactment' became destabilized, and the new primary meaning became simply 'imitation'. This destabilization, caused by a gradual weakening of ritual practices in general, led to a new secondary meaning of mimesis, which can best be translated as 'representation'. Unlike reenactment as I have defined it, representation can be devoid of ritual. ${ }^{7}$

For my working definition of mimesis, I have just used the word ritual. For a working definition of this term, I reapply Stanley Tambiah's formulation of ritual as "a culturally constructed system of symbolic communication." Keeping in mind this broad working definition of ritual, I argue that myth-or at least the performance of myth as song, poetry, or prose-can be seen as an aspect of ritual, though of course myth is $\{228 \mid 229\}$ also potentially distinguishable from ritual. ${ }^{9}$ And I add here a working definition of myth: it is a given traditional society's coding of truth-values through narrative. ${ }^{10}$

\section{The Delian Maidens in the Homeric Hymn (3) to Apollo}

Here is the full text of the description of the Delian Maidens in the Homeric Hymn (3) to Apollo:

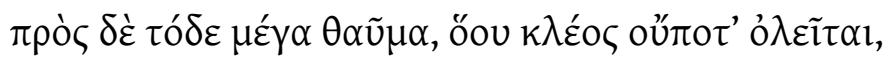

\footnotetext{
${ }^{7}$ This paragraph is a distillation of my detailed argumentation in PH 42-45, 346, 349, 373-375, 381, 387, 411.

${ }^{8}$ Tambiah 1985:128. My original applications had been worked out in the Introduction to $\mathrm{PH}$.

${ }^{9}$ I offer the formulation "myth implies ritual in the very performance of myth" in Nagy 1989:xi and in Nagy 1992:317.

${ }^{10}$ Elaborations in 1990b:8 (this work is hereafter abbreviated as GM); cf. PH 313-317.
} 


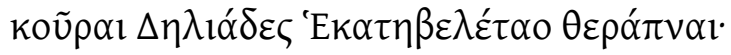

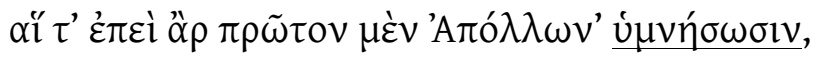

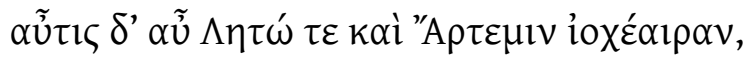

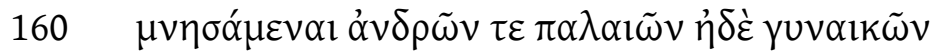

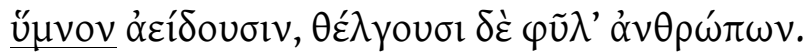

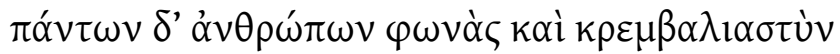

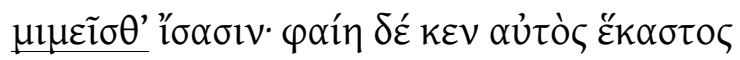

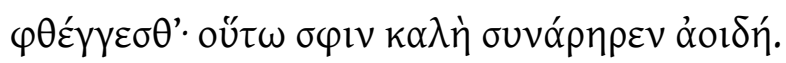

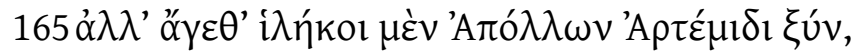

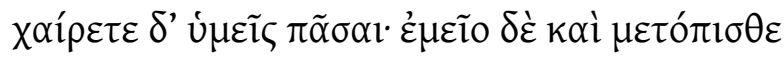

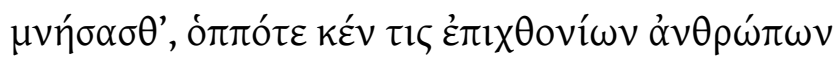

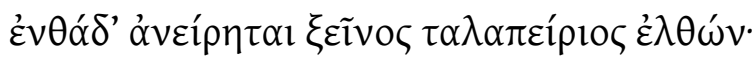

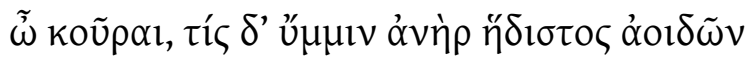

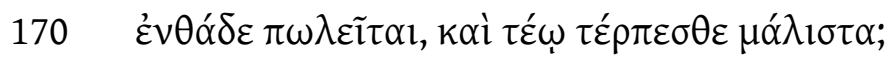

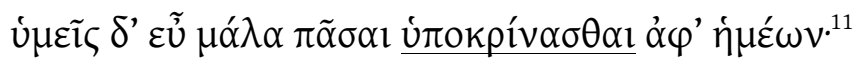

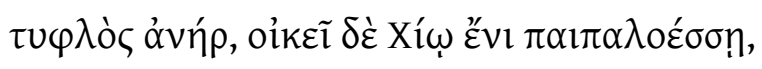

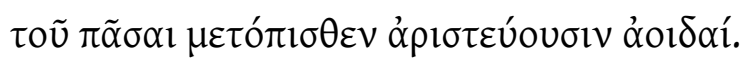

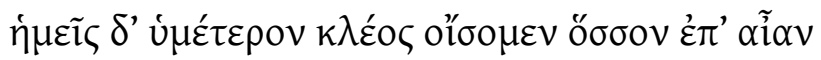

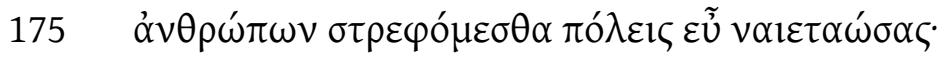

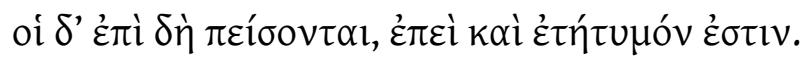

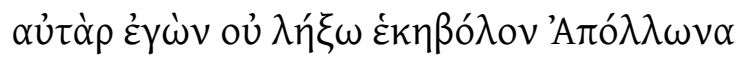

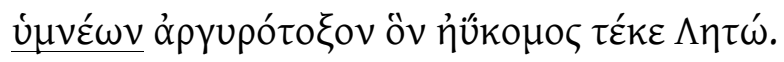

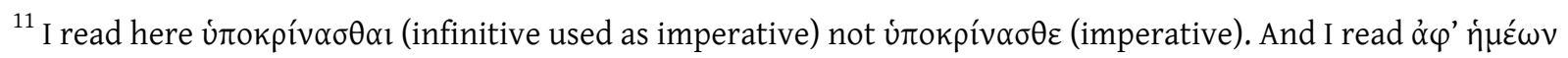
not $\dot{\alpha}_{\mu} \varphi^{\prime} \dot{\eta} \mu \varepsilon \dot{c} \omega \nu$ (both textual variants are attested in the medieval manuscript tradition).
} 
And then, there is this great thing of wonder [thauma], the fame [kleos] of which will never perish:

the Delian Maidens, attendants [therapnai] of the one who shoots from afar. $\{229 \mid 230\}$

$\mathrm{So}^{12}$ when they make Apollo their humnos ${ }^{13}$ first and foremost, and then Leto and Artemis, shooter of arrows, 160they keep in mind men of the past and women too, as they sing the humnos, and they enchant all different kinds of humanity. All humans' voices and rhythms ${ }^{14}$

they know how to reenact [mimeîsthai]. And each single person would say that his own voice

was their voice. That is how their beautiful song has each of its parts fitting together [sun-arariskein] in place.

165 But come now, may Apollo be gracious, along with Artemis;

and you all also, hail and take pleasure [khairete], all of you [Maidens of Delos]. Keep me, even in the future, in your mind, whenever someone, out of the whole mass of earthbound humanity,

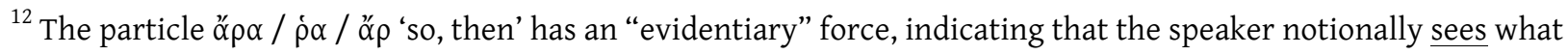
is simultaneously being spoken. See Bakker 2005:12n, 80, 84, 97-100, 104, 146, 172n33.

${ }^{13}$ On the occasion of singing a humnos, the god who is being sung in the humnos - who is the subject of the humnos - is metonymically equated with the humnos itself: by metonymy, the god is the song.

${ }^{14}$ A variant reading here is bambaliastus. See PH 43. The noun krembaliastus indicates the creation of rhythm by way of musical instruments of percussion, such as krotala, and this rhythm is distinctly choral: see the argumentation of Peponi 2009, who also adduces iconographical evidence showing the Muses themselves in the act of singing and dancing while playing on krotala.
} 
comes here [to Delos], after arduous wandering, as a guest entitled to the rules of hosting, and asks this question:

"O Maidens, who is for you the most pleasurable of singers

170that wanders here? In whom do you take the most delight [terpesthai]?"

Then you, all of you [Maidens of Delos], must very properly respond [hupokrinesthai] about me: $:^{15}$

"It is a blind man, and he dwells [oikeîn] in Chios, a rugged land, and all his songs will in the future prevail as the very best." And $\mathrm{I}^{16}$ in turn will carry your fame [kleos] as far over the earth 175 as I wander, throughout the cities of men, with their fair populations. $\{230 \mid 231\}$ And they will all believe - I now see - since it is genuine [etētumon]. As for me, I will not leave off [lēgein] making far-shooting Apollo my humnos, ${ }^{17}$ the one with the silver quiver, who was born of Leto with the beautiful hair.

Homeric Hymn (3) to Apollo 156-178

\footnotetext{
${ }^{15}$ In a quotation made by Thucydides (3.104.5) from the Homeric Hymn to Apollo, we find an alternative reading in place of the phrase $\alpha \dot{\varphi}$ ' $\dot{\eta} \mu \varepsilon \varepsilon^{\prime} \omega v$ 'about me' as attested here at verse 171 of the Hymn: that alternative reading is

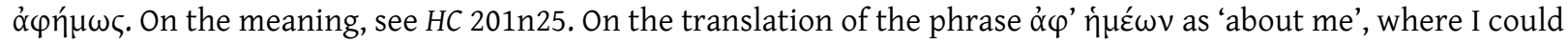
have rendered it more literally as 'about us', see the next note.

${ }^{16}$ I translate as 'I' the Greek word $\mathfrak{\eta} \mu \varepsilon \tilde{\imath} \zeta$ here at verse 174 of the Hymn, though it means literally, 'we'. In Homeric diction, the speaking ' $I$ ' who is the master narrator, as in Odyssey i 1 , is interchangeable with a speaking 'we', as in Odyssey i 10. Such interchangeability is relevant to the role of the speaker in this Hymn, as we will see at a later point in my argumentation.

${ }^{17}$ Once again, the god who is being sung in the humnos - who is the subject of the humnos - is metonymically equated with the humnos itself: by metonymy, the god is the song.
} 


\section{Four words relating to the mimesis performed by the Delian Maidens}

I have selected from this passage four words that will prove to be essential for my overall argumentation about the mimesis performed by the Delian Maidens in the Homeric Hymn to Apollo.

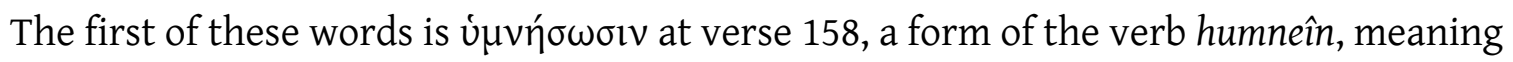
'make a humnos' or 'make someone [in particular, a divinity] the subject of a humnos'. This verb is derived from the noun humnos, ordinarily translated in its narrow sense of 'hymn'. In the present context, the form refers to the performance of the Delian Maidens, which I will argue is a choral performance. And it refers also to the performance of the actual Homeric Hymn to Apollo, which is a humnos in the narrow sense of a 'hymn' as used in the conventional title Homeric Hymn (3) to Apollo. I must add that ن́uvéwv at verse 178, referring to the solo performance of the 'hymn' by the speaker of the Homeric Hymn to Apollo, is a form of the same verb humneîn and shows the same meaning 'make a humnos' or 'make someone [in particular, a

divinity] the subject of a humnos'. As I will argue, it is as if a choral performance of a humnos to Apollo by the Delian Maidens were the same thing as the solo performance of the actual Hymn to Apollo. When I say as if it were the same thing here, I am referring to the mental activity of mimesis as I highlighted it in the Introduction. I will have more to say later about the interaction of solo and choral performances as dramatized by way of mimesis in the Hymn to Apollo.

The second of the four words I have selected from the passage I just quoted from the Hymn to Apollo is ü $\mu v o v$ at verse 161 , accusative of the noun humnos. In the present context, it refers to the performance of the Delian Maidens, even as it extends beyond the actual Hymn. Here the word humnos is used in the broader sense of a 'song' as we see it used also in Odyssey viii 420, where this same word refers to the entirety of a $\{231 \mid 232\}$ performance, as opposed to the 
narrower sense of a 'hymn' to a divinity. ${ }^{18}$ In that narrower sense, a humnos is only a part of a performance and simply introduces the rest of the performance. ${ }^{19}$ In terms of the broader sense of humnos, however, the Delian Maidens are a model for the making of a whole song, not only for the making of a hymn that introduces the whole song. When I say model here, I am referring once again to the mental activity of mimesis as I highlighted it in the Introduction. I will have more to say later about the reenactment of models by way of mimesis.

The third of the four selected words is $\mu \iota \mu \varepsilon \tilde{\sigma} \sigma$ ' at verse 163. This verb mimeîsthai 'reenact, imitate', along with its derivative noun mimēsis (mimesis), is the centerpoint of my overall argumentation..$^{20}$ As I have argued in Poetry as Performance (1996) and as I argue in more detail here, these two words convey the central idea of theatrical performance by a chorus of singing and dancing performers. ${ }^{21}$ The wording of the Homeric Hymn (3) to Apollo indicates that the

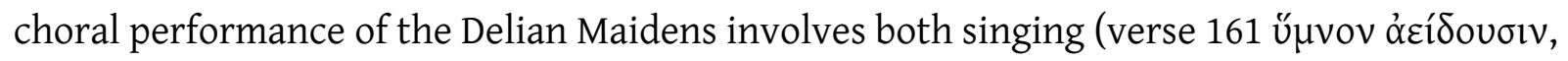
verse 164 ơol $\delta$ ) ) and dancing to the rhythm of percussive instruments (verse 162 $\left.\kappa \rho \varepsilon \mu \beta \alpha \lambda_{\imath} \alpha \sigma \tau u ́ v\right) .^{22}$

The last of the four words I have selected from the passage I quoted from the Hymn to Apollo is úrokpív $\alpha \sigma \theta \alpha l$ at verse 171 , which I interpret as the aorist infinitive (used as an imperative) of the verb hupokrinesthai 'respond'. In this context, the quoted words of the Maidens in the Hymn are in effect 'responding' to the question that the unnamed wanderer is asking: who is

\footnotetext{
${ }^{18}$ HC 313-326.

${ }^{19}$ HC 312-313.

${ }^{20}$ The combination of $\mu \mu \varepsilon \tilde{\varepsilon} \sigma \theta$ ' with '̌o $\sigma \sigma v$ can best be understood by comparing the usage of oĩ $\delta \alpha$ in Archilochus, on which see HC 217-218.

${ }^{21}$ PP 80-81. Here and hereafter, I use the term theatrical as a synonym of dramatic in a technical sense, that is, related to performance in drama.

${ }^{22}$ Peponi 2009. She notes the iconographical evidence showing Muses in the act of dancing to the rhythm of percussive instruments. The parallelism of the Muses and the Delian Maidens in this regard is relevant to what I have to say later about other such parallelisms.
} 
the best of all singers? As in the case of mimeisthai 'reenact, imitate' at verse 163, so also in this case of hupokrinesthai 'respond' here at verse 171, I will argue that this word conveys the idea of theatrical performance by a chorus. The 'responsion' conveyed by hupokrinesthai at verse 171 is theatrical, and it is related to the usages of the same verb hupokrinesthai and of its agent noun hupokritēs in prose, where these two words mean respectively 'act' and 'actor' in the context of the theatron 'theater', especially the theater of tragedy ${ }^{23}$ As we will see, the theatricality conveyed by way of the word hupokrinesthai 'respond' at verse 171 is made explicit, at verse 163, by way of the word mimeîsthai 'reenact, imitate'. $\{232 \mid 233\}$

\section{The making of mimesis by the chorus}

I start with an observation made by Walter Burkert about the context of mimeisthai 'reenact, imitate' at verse 163 in the Homeric Hymn (3) to Apollo. He interprets verses 162-165, where the speaker of the Hymn encounters the Delian Maidens at a festival on the island of Delos, as a reference to the "performance of choral lyrics." ${ }^{24}$ In my own work, I have built on this observation by advancing the argument that the Delian Maidens in the Hymn represent an idealization of choral lyric. ${ }^{25}$ I argue further that these Maidens "are presented in the Hymn as archetypes meant to be reenacted in the local ritual context of real choral performances at Delos-in which context the choral participants would be equated, for the ritual moment, with the archetypal Maidens. ${ }^{26}$ Such a reenactment is mimesis in the primary sense that I outlined in the Introduction.

\footnotetext{
${ }^{23}$ HC 92-93.

${ }^{24}$ Burkert 1987:54.

${ }^{25} \mathrm{PH} 43,375-377$; TCL 45.

${ }^{26}$ PP 56; this formulation is quoted with approval by Henrichs 1996:58n35.
} 
So, what would be the basic form of such choral lyric performance? A more accurate term for this form is choral song and dance. And the choral singing and dancing was a ritual activity. The definitive work on the ritual background of choral song and dance is a two-volume book by Claude Calame on choruses in archaic Greece (1977). ${ }^{27}$ The subtitle of the first volume, Morphologie, fonction religieuse et sociale, captures a central insight concerning choruses of female performers in particular and choruses in general, which Calame himself articulates in the course of his prodigiously exhaustive collection of data. The insight is this: the archaic Greek chorus has a fundamentally social and even religious function as a holistic expression of the given society for which the given chorus performs ${ }^{28}$ The term religious function in this formulation can be described in terms of ritual as I defined it in the Introduction.

A premier example of the ritual function of choral song and dance as analyzed by Calame is Song 1 of the poet Alcman, who flourished in the seventh century BCE (my numbering follows the PMG edition of Page). This song, the so-called Partheneion or 'Maiden-Song', was a choral composition destined for performance in archaic Sparta. ${ }^{29}$ And the archetypal figures in this song, including the primary archetypal figures named Hagesikhora and Agido, were acted out by the choral participants in performances held on a seasonally recurring basis. ${ }^{30}\{233 \mid 234\}$

The insight of Calame about the ritual function of archaic choral lyric applies also to the classical choral lyric of Athenian State Theater. ${ }^{31}$ In all four of the genres of drama performed in Athenian State Theater-tragedy, comedy, satyr drama, and dithyramb-there is an analogous ritual function in the choral singing and dancing that we find embedded in the

\footnotetext{
${ }^{27}$ The definitive second edition is Calame 2001.

${ }^{28}$ I first formulated this paraphrase of Calame's insight in TCL 44.

${ }^{29}$ For more on the Partheneion of Alcman, see Ferrari 2008.

${ }^{30}$ PH 345-370; TCL 45. See also Clay 1991.

${ }^{31}$ What I say here was the main point of TLC.
} 
drama. As Richard Seaford says about classical tragedy in particular, a historical study of the overall structure of such drama confirms that "the performance of tragedy originated in the practice of ritual. ${ }^{32}$

\section{The democratizing of choral lyric}

There is a major difference in the ritual function of the archaic and the classical forms of choral singing and dancing. For an understanding of this difference I turn to a formulation by Burkert, who notes that the archaic chorus is aristocratic, whereas the classical chorus of Athenian State Theater has been radically democratized. ${ }^{33}$ Burkert highlights a reference by the "Old Oligarch," also known as "pseudo-Xenophon" (Constitution of Athens 1.13), concerning a lavish form of choral performance traditions that reportedly became obsolete in Athens under the democracy: "Stripped of its polemical overtones, this [reference by the Old Oligarch] remains an interesting account of musical events before the democratic revolutions." ${ }^{34}$ In predemocratic Athens, as Burkert argues, choral performance traditions most closely resembled what we see in the archaic choral songmaking of the poet Stesichorus, whose lifetime straddles the seventh and the sixth century BCE and whose songs are the main point of interest for Burkert. I will have more to say later about the songmaking of Stesichorus.

In Plato's works, the democratization in the Athenian songmaking traditions of choral lyric is conveyed by the negative term theatrokratia (Laws 3.701a), implying dèmokratia. ${ }^{35}$ This term theatrokratia describes the democratized state of the arts in the classical era of Athens, in contrast with the aristokratia of the "good old days," as in the era preceding the Persian Wars

\footnotetext{
${ }^{32}$ Seaford 1984:14; PH 30.

33 Burkert 1987:52.

${ }^{34}$ Burkert 1987:52.

${ }^{35}$ TLC 47. See also Laws 2.658a-659c, 669b-670b, and the comments by Svenbro 1984:231n133.
} 
(Laws 3.698b-700a), when there were still distinct eidē or 'genres' ${ }^{36}$ Five examples are mentioned, of which four are choral in nature: humnos 'hymn', thrēnos 'lament', paian 'paean', and dithurambos 'dithyramb' (Laws 3.700b) ${ }^{37}\{234 \mid 235\}$ These genres, as structurally distinct forms of choral songmaking, correspond to the structurally distinct aspects of aristokratia in Plato's good old Athenian society (Laws 3.701a). ${ }^{38}$

The starting point for the theatrocracy that Plato takes back in time to the era of the Persian Wars can in fact be taken back even farther, all the way to the earliest recoverable phases in the evolution of Athenian State Theater in the sixth century BCE. ${ }^{39}$ From a historical perspective, I offer this formulation of theatrocracy and its effects: in the choral parts of the composite genre of tragedy and in the other composite genres of Athenian State Theater, namely, in comedy and in the satyr drama, we can see the assimilation of various different genres of choral songmaking that are still independent and unassimilated in the repertoire of an archaizing poet like Pindar, who flourished in the first half of the fifth century BCE and who is credited with compositions that fit the distinct categories of choral genres like the humnos 'hymn', thrēnos 'lament', paian 'paean', and dithurambos 'dithyramb' .

Such assimilation of genres, as I will argue, can be explained in terms of mimesis as practiced in the choral parts of the composite genre of tragedy and in the other composite

\footnotetext{
${ }^{36}$ On the appropriateness of translating eide as genres here, see again Svenbro 1984:225, 232n135.

${ }^{37}$ Further discussion of all five examples in PH 108-109, 401, 403. The fifth example, the kitharoidikos nomos 'citharodic nome' (Laws 3.700b), can be described as a virtuoso monodic offshoot of choral performance: see $\mathrm{PH}$ 86-87, 340-341, 357-358.

${ }^{38}$ Cf. Svenbro 1984:225. On the appropriation, by Athenian State Theater, of the songmaking traditions of lamentation, see Loraux 1998:10-11.

${ }^{39}$ TCL $47-48$.

${ }^{40}$ This formulation is based on an earlier formulation in PH 403. I need to repeat here what I said at the beginning, that the dithyramb, unlike tragedy, comedy, and the satyr drama, is not a composite genre, since it is entirely choral.
} 
genres of Athenian State Theater. And a prototype of this kind of mimesis, as I will also argue, is reflected in the reference made in the Homeric Hymn (3) to Apollo to the Delian Maidens as practitioners of mimesis (163 mimeîsthai).

\section{Homer's Delian Maidens and Hesiod's Muses as models of mimesis}

At verses 161-164 of the Homeric Hymn (3) to Apollo, the text of which I will reexamine at a later point, the Delian Maidens are described as having the power to make a mimesis of the voices of all people. In Pindar's Homer, I argued that such mimesis, as practiced by the Maidens, extends to the voice of Homer himself. In terms of that argument, the Maidens in this Hymn are in effect offering to make a mimesis of Homer, that is, to 'reenact' him, and Homer responds by making a mimesis of them. ${ }^{41}$ I return to that $\{235 \mid 236\}$ argument here, enhancing it with further argumentation. And I will focus on a set of similarities that link the Delian Maidens as represented in the Hymn with the Muses as represented in the Hesiodic Theogony.

At the core of these similarities is the relationship between poets and Muses. In archaic Greek poetry, formulaic descriptions of the Muses are closely related to formulaic descriptions of the generic poet or aoidos 'singer' ${ }^{42}$ The characteristics of the Muses, as defined in formulas describing them, reflect the characteristics of the aoidos in a variety of performative contexts. ${ }^{43}$

These performative contexts include situations where the aoidos is interacting with a chorus. The compositions of Alcman known as partheneia 'maiden-songs' are a case in point: here we see a variety of ritual situations where the aoidos is interacting with a chorus

\footnotetext{
${ }^{41}$ PH 375-376; see also PP 82.

${ }^{42}$ Nagy 1979 (hereafter BA) 296-297.

${ }^{43}$ BA 301-307.
} 
composed of elite local girls of Sparta who, at the moment of singing and dancing, are notionally reenacting the singing and dancing of local goddesses (as in Alcman PMG 1). ${ }^{44}$

And the Muses themselves can be idealized as a chorus of local goddesses who perform their choral song and dance in a locale that is sacred to them. ${ }^{45}$ When the Muses in the Hesiodic Theogony are imagined as starting the performance of their song, which is a theogony in its own right and thus a model for Hesiod the aoidos, they perform in the mode of a khoros (this is the word that is used), a 'chorus' of local goddesses singing and dancing in a locale sacred to them, Mount Helicon (Theogony 3-4, 70). This kind of modeling, I argue, is the essence of mimesis as performed by the Muses.

The relationship between the aoidos of the Hesiodic Theogony and the chorus of Heliconian Muses is matched by the relationship between the aoidos of the Homeric Hymn to Apollo and the Delian Maidens, as we see it dramatized in the passage I quoted and translated from the Hymn. These Maidens, described as the therapnai 'attendants' of the god Apollo (157), are addressed by the poet of this Homeric Hymn with the hymnic salutation khairete (166), in conjunction with the god Apollo (165). ${ }^{46}$ I translate this salutation as 'hail and take pleasure': the verb khairein is related to the noun kharis, which conveys the idea of 'favor' or 'graciousness' in the sense of reciprocated beauty and pleasure. ${ }^{47}$ With his salutation of khairete (166), the aoidos is asking the Delian Maidens to accept the kharis 'favor' of his song and to give him their 'favor', their kharis, in return. The hymnic salutation khaire or khairete is used in the Homeric Hymns to address the given god $\{236 \mid 237\}$ or gods presiding over the performance of each given hymn. Similarly in the Hesiodic Theogony, the figure of Hesiod addresses the Muses with the hymnic salutation

\footnotetext{
${ }^{44}$ PH 346-347; PP 53-54, 57, 89-90, 92, 96.

${ }^{45}$ GM 57-58.

${ }^{46}$ GM 58.

${ }^{47}$ Nagy 2002 (hereafter PR) 82n37. See now also Calame 2005:26-28.
} 
khairete (104) in the context of naming them, in conjunction with Apollo, as the divine sources of poetic power (94-95). In the Homeric Hymn (3) to Apollo, as I argue, the aoidos who addresses the Delian Maidens with the hymnic salutation khairete is imagined as Homer himself. ${ }^{48}$ This way of imagining the aoidos extends into the classical period, as we see from the testimony of Thucydides (3.104.4), who says outright that the poet of the Homeric Hymn to Apollo is Homer.

The figure of Homer addresses the Delian Maidens with the hymnic salutation khairete in the Homeric Hymn (3) to Apollo (166) just as the figure of Hesiod addresses the Olympian Muses with the hymnic salutation khairete in the Theogony (104). This parallelism indicates that Homer is in effect addressing the local Muses of Delos, who are divine in their own right. It is not a contradiction, however, to maintain that the Delian Maidens are simultaneously envisioned as members of a local khoros 'chorus' of girls or women. ${ }^{49}$ As I pointed out a moment ago with reference to Alcman's partheneia 'maiden-songs', the role of divinity can be appropriated by members of a chorus during choral performance. So the Delian Maidens as a choral ensemble can reenact the local Delian Muses. ${ }^{50}$

Homer's dramatized encounter with the Delian Maidens is comparable to Hesiod's dramatized encounter with the local Muses of Mount Helicon (Theogony 22-34), which leads to the transformation of their local theogony into the Panhellenic Theogony sung by Hesiod-and to their own transformation into the Panhellenic Muses of Mount Olympus (verses 52 and

\footnotetext{
${ }^{48}$ PH 375-376; PP 82.

${ }^{49}$ See Peponi 2009:54-55, 66n71. Also Calame 2001:30, 104, 110. Thucydides 3.104.5 refers to this chorus as gunaikes 'women'; accordingly, it may be too restrictive to say 'Delian Maidens', if the categories of choral groupings included women as well as unmarried 'maidens'; in that case, it may be preferable to use a more inclusive translation, 'Deliades'. See HC 204n36.

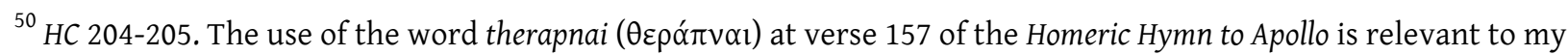
argument: as Marianne Hopman and Renaud Gagné point out to me, this word therapnai could refer simultaneously to the Delian Maidens as worshippers-that is, as local attendants in the sanctuary of Apollo-and as mythical followers of the god. This way, the Delian Maidens are simultaneously a local khoros of Delian women and the archetypal Muses abiding on the island of Delos.
} 
thereafter). ${ }^{51}$ The Panhellenization of the Heliconian Muses is a matter of reciprocation: they are transformed into Olympian Muses because they transform Hesiod, who is implicitly a generic aoidos 'singer' and master of kleos 'fame' (Theogony 99-101). They transform Hesiod into a Panhellenic figure in his own right, who articulates a single Theogony that notionally $\{237 \mid 238\}$ supersedes all other potential theogonies in its truth value $(22-34) .{ }^{52}$ Further, the local humnos of the Heliconian Muses has been transformed into the Panhellenic humnos of the Olympian Muses. The Hesiodic Theogony ultimately defines itself as one single continuous gigantic humnos. ${ }^{53}$

Similarly in the Homeric Hymn (3) to Apollo, the dramatized encounter of the aoidos with the local Delian Maidens leads to the transformation of their local humnos 'hymn' to Apollo

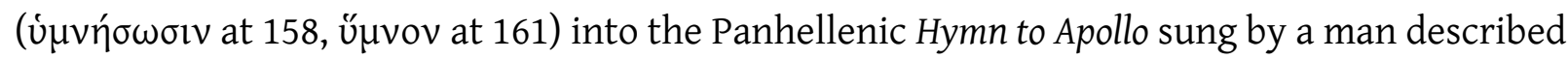
as 'the most pleasing of all singers [aoidoi]' (169). This aoidos 'singer' is further described, in the words of the Delian Maidens, as a blind man whose home is on the island of Chios (172). His aoidai 'songs', as the words of the Delian Maidens prophesy, will be supreme, performed throughout the cities of humankind (173-175). ${ }^{54}$

This aoidos of the Homeric Hymn (3) to Apollo, like Hesiod, is a master of kleos 'fame': he speaks about the kleos of the hymn performed by the Delian Maidens (Hymn to Apollo 156), and he promises that he will spread that kleos (174) throughout all the cities he visits (173-175). The Panhellenization of the Delian Maidens, like the Panhellenization of the Heliconian Muses, is a matter of reciprocated kleos. And it is also a matter of reciprocated mimesis. ${ }^{55}$

\footnotetext{
${ }^{51}$ GM 58.

${ }^{52}$ HQ 124-128.

${ }^{53}$ HC 205.

${ }^{54}$ HC 205.

${ }^{55}$ HC 205.
} 
In the Hymn, the description of the blind aoidos from Chios who will spread the kleos of the Delian Maidens throughout the cities of humankind (172-175) starts with a quotation spoken by the Delian Maidens (172-173) in response to an unnamed wanderer, 'someone' (tis) who arrives in Delos and asks the Delian Maidens this question: who is the best aoidos of all? (169-

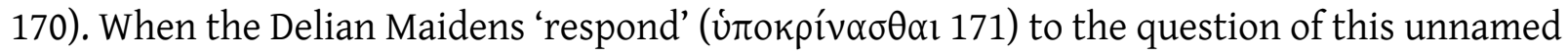
wanderer, of this 'someone', it is the quotation of their performed words that reciprocates the kleos: the quoted response of the Maidens (173-175) identifies the best aoidos with the aoidos who quotes their response about him, who will confer kleos on the Delian Maidens as he wanders throughout the cities of humankind..$^{56}$

In the riddling language of the Homeric Hymn (3) to Apollo, the unnamed wanderer to Delos, this 'someone' whose question to the Delian Maidens is quoted in the Hymn (169-170), can be the same persona as the unnamed aoidos 'singer' of the Hymn who quotes the response of the Delian Maidens (172-173), who is the same persona as the unnamed aoidos who will now wander from Delos to all the cities of humankind, a bearer of the kleos 'fame' that is reciprocated between him and the Maidens (174-175). This composite unnamed persona is the figure of Homer himself. ${ }^{57}\{238 \mid 239\}$

The identity of Homer in the Homeric Hymn (3) to Apollo is expressed by way of riddling and even mantic speech. The description of the 'someone' who has reached Delos after arduous wanderings (167-168) anticipates the response (174-175) to the question 'who?' (169-170). That response (174-175) pictures the master singer who wanders throughout the cities of humankind. But this master singer is not explicitly named as Homer. Instead, his identity is implicit in the riddle posed by the question: he is the answer to the question 'who?'-but he is

\footnotetext{
${ }^{56}$ HC 205.

${ }^{57}$ HC 205-206.
} 
also the 'someone' that asks the question 'who?' The response of the Delian Maidens is Homer's own response, since their response is quoted by him. The singer who leaves Delos with an answer loops back to the singer who arrives at Delos with a question. ${ }^{58}$ This looping effect has its own significance: each time this wandering minstrel arrives at Delos, he becomes a regeneration of Homer as he sings in Delos. Each time the figure of Homer is pictured as singing in Delos, the Delian Maidens authorize him all over again. The eternal return of Homer is made possible by the notionally eternal recycling of his songs. ${ }^{59}$

Here I come back full circle to what I proposed at the start of this section, that the Delian Maidens of the Homeric Hymn (3) to Apollo are in effect offering to make a mimesis 'reenactment, imitation' of Homer, and that Homer responds by making a mimesis 'reenactment, imitation' of them. In the mythical world of the Homeric Hymn to Apollo, epic performance is being assimilated to a theatrical performance by an idealized chorus of local Muses, the Delian Maidens.

In terms of the model I am building to explain the traditions of performance at festivals, a theatrical word like mimeîsthai in the Homeric Hymn (3) to Apollo (line 171) reveals an early phase of an ongoing symbiosis of two elements: one is the Homeric tradition as it evolved at the Athenian festival of the Panathenaia and the other is the theatrical tradition of drama as it

\footnotetext{
${ }^{58}$ HC 206. In the Homeric Hymn to Apollo (168), according to the version quoted by Thucydides 3.104.5, the wanderer who arrives at Delos is described as allos-seemingly some person 'other' than the speaker. Even in terms of this variant, my formulation holds: this seemingly 'other' person becomes the same person as the speaker-once the response of the Delian Maidens to that 'other' person is actually quoted by the speaker.

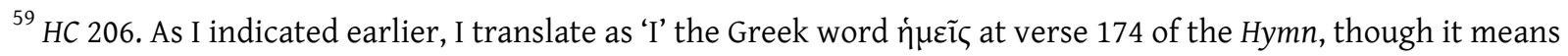
literally, 'we'. In Homeric diction, as I also indicated earlier, the speaking 'I' who is the master narrator, as in Odyssey i 1 , is interchangeable with a speaking 'we', as in Odyssey i 10. I have by now reached a point in my argumentation where I can offer an explanation. Such an elliptic speaking 'we' implies that the persona of the speaking 'I' is the latest in a succession, through time, of previous speakers. I develop a model for such a succession of speakers in PP 214-225.
} 
evolved at the Athenian festival of the City Dionysia. ${ }^{60}$ As I argue in $\{239 \mid 240\}$ Homer the Classic, such symbiosis was facilitated by the medium of the humnos 'hymn' or enkōmion 'encomium, celebration, song of praise'-whether or not Aristotle is right in thinking of this medium as an undifferentiated prototype of epic and tragedy. ${ }^{61}$

From Aristotle's point of view, the prototype of the humnos or enkomion was a choral medium. This medium's eventual differentiation into epic and tragedy involved the individuation of its leading performers. That is, the performances of soloists emerged out of an ensemble of choral performers. Further, there was a differentiation of roles: a speaker of words was singled out from among an ensemble of singers and dancers. Such differentiation, as I argue in Homer the Classic, is conveyed by Aristotle's use of the technical term exarkhein, in the sense of 'leading' a chorus. ${ }^{62}$ For Aristotle, the exarkhōn or 'leader' of a chorus was a prototypical actor in drama, whose lexis or 'speech' was differentiated from the rest of the singing and dancing performed by the chorus.

In the Poetics, Aristotle develops his theory of differentiation in the broader context of reconstructing the prehistory of the four dramatic genres of the City Dionysia in Athens: tragedy, comedy, satyr drama, and dithyramb. In terms of Aristotle's reconstruction, all four of these dramatic genres resulted from progressive differentiations of earlier and less differentiated forms of choral performances. ${ }^{63}$ By choral performances I mean of course the singing and dancing of choral ensembles at festivals.

\footnotetext{
${ }^{60}$ PP 81. The symmetry of the Panathenaia and the City Dionysia as the two most important festivals of the Athenians is evident in a formulation by Demosthenes in the First Philippic (4.35).

${ }^{61}$ HC 214. I note there that Aristotle's use of the terms humnos 'hymn' and enkōmion 'encomium, celebration, song of praise' is comparable to Plato's use of the terms humnos and ekomiazein in the Timaeus (21a).

${ }^{62}$ HC 214.

${ }^{63}$ PH 384-392.
} 
I draw this section to a close by emphasizing that mimesis is a feature of both choral performance and monodic performance as individuated from choral performance. Monodic performance can make a mimesis of choral performance, as we see in the Homeric Hymn to Apollo, but choral performance can also make mimesis, and it can do so outside of Athenian State Theater. Choral performance can make a mimesis of either (1) other choral performances or (2) even monodic performances.

\section{Choral performance as a nonprofessional activity}

So far, my argumentation has supported the observation of Burkert concerning verses 162165 in the Homeric Hymn (3) to Apollo, which include the mention of mimesis at verse 163 (mimeîsthai). I have agreed with him that these verses refer to the "performance of choral lyrics. ${ }^{\prime \prime 4}$ And I also agree $\{240 \mid 241\}$ with his overall argument that the idealized performance of the Delian Maidens, as represented in the Homeric Hymn, is analogous to the historical performances of choruses in the archaic period, as in the case of the choral songmaking attributed to Stesichorus. But now I come to a point of disagreement. Specifically, I disagree with Burkert's view that those who performed the singing and dancing in such archaic choruses were itinerant professionals. ${ }^{65}$ It seems clear, especially from the evidence assembled in Calame's book on choruses, that performers who participated in choruses during the archaic period were not professionals, and that the nonprofessionalism of the choral participants was linked with the fact that choral participation was grounded in the ritual heritage of the community to which the participants belonged. ${ }^{66}$

\footnotetext{
${ }^{64}$ Burkert 1987:54.

${ }^{65} \mathrm{PH} 362 \mathrm{n} 124$, with reference to the arguments of Burkert 1987:51-52.

${ }^{66} \mathrm{PH} 85,104,106,113,188-190,340-342,343,362,379,405$.
} 
In arguing that those who performed the singing and dancing in archaic choruses were professionals, Burkert offers the following formulation, with reference to the testimony of the anonymous Athenian author conventionally known as the "Old Oligarch":

We have at least one piece of testimony that professional foreign musicians performed in Athens in the sixth century: the "Old Oligarch" [pseudoXenophon, Constitution of the Athenians 1.13] states that 'the demos has abolished here [= at Athens] those who performed sports and music. They decreed this was not honorable, because (in reality) they knew (but too well) that they could

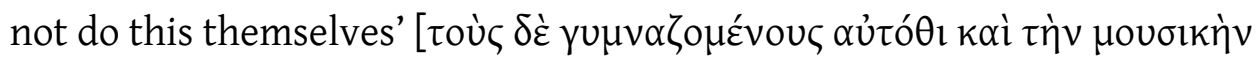

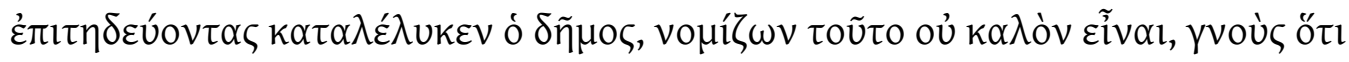

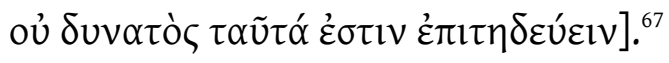

As I interpret the original Greek wording of this statement by the Old Oligarch, he is saying something different from what we see in the translation offered by Burkert. However slanted the views of the Old Oligarch may be when he speaks of the democratic State or Demos, his wording reflects accurately the historical circumstances that provoke those views. As I interpret the wording, he is not saying that the aristocrats of Athens in the archaic period were professionals when they sang and danced at choral events. It is quite the opposite. They were ostentatiously nonprofessional-just as they were ostentatiously nonprofessional when they participated in athletic events. The original Greek phrase tous de gumnazomenous ... kai tēn mousikên epitēdeuontas needs to be rendered not as 'those who performed sports and music' but rather as 'those who performed in athletic and in songmaking events', where the mousike or

\footnotetext{
${ }^{67}$ Burkert 1987:52.
} 
'songmaking' includes $\{241 \mid 242\}$ choral singing and dancing. ${ }^{68}$ We can know for sure that the Old Oligarch has in mind a pairing of choral events with athletic events in this context because he goes on to say (Constitution of the Athenians 1.13) that the Demos tampered with aristocratic institutions by establishing democratic institutions of choral leadership and athletic leadership, khorēgia and gumnasiarkhia, where the rank and file are being led by khorēgoi 'chorus leaders' and gumnasiarkhoi 'athletics leaders' selected from the stratum of society that is rich enough to finance these activities, and thus 'the Demos thinks it proper to get money

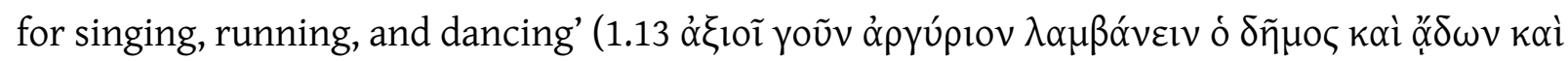

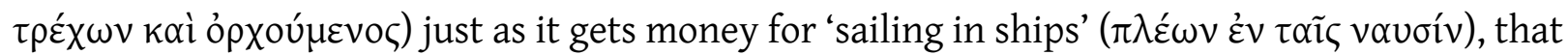
is, for manning the warships or triremes of the Athenian navy.

From the standpoint of the Old Oligarch, the nonaristocrats who represented the democratic State or Demos did not appreciate the beauty of nonprofessional athletic and choral events as practiced by the aristocrats, thinking that the whole thing was not kalon, not really 'beautiful' (here I resist the translation adopted by Burkert: 'honorable'), and, in their spitefulness, they passed legislation that was designed to commercialize athletic and choral activities as well as the military activity of serving in the navy. And such commercialization, as we will see, led to the professionalization of Athenian State Theater.

Pursuing my reinterpretation, I now offer a retranslation of the relevant passage taken from the Old Oligarch (1.13):

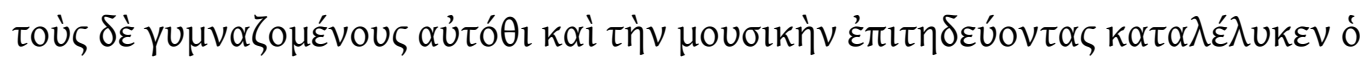

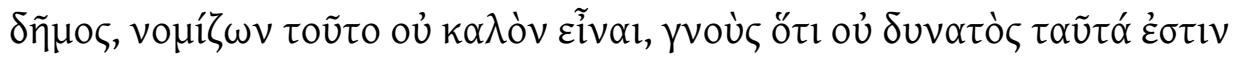

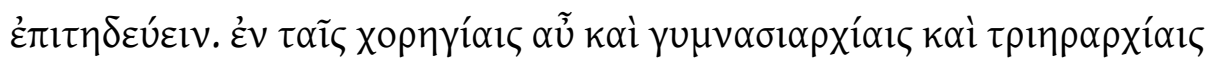

\footnotetext{
${ }^{68}$ On the use of the word mousike as a term for the art of making poetry or song, including choral singing and dancing, see HC 362-373.
} 


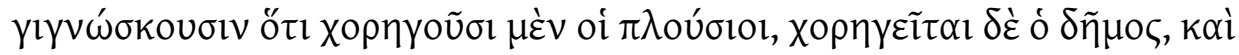

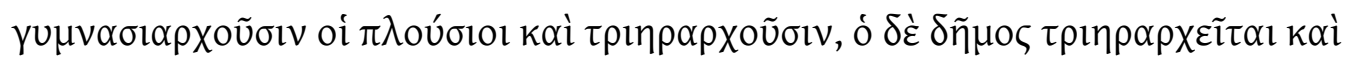

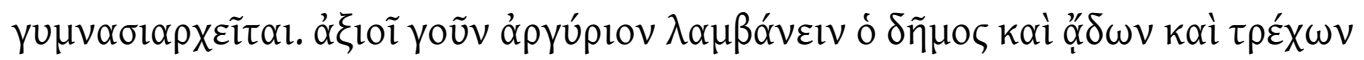

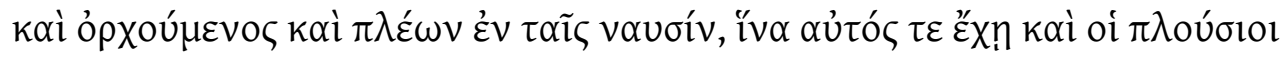
$\pi \varepsilon v \varepsilon ́ \sigma \tau \varepsilon \rho o l ~ \gamma i ́ \gamma v \omega \nu \tau \alpha \mathrm{l}$.

The Demos here [= at Athens] has stopped those [= the aristocrats] who practice athletics and who pursue the practice of songmaking mousike. They [= the nonaristocrats as represented by the Demos] express the view that this [= the entirety of these practices] is not really beautiful, because they know all too well that they [= the nonaristocrats] are unable to pursue these practices themselves. Moreover, when it comes to the institutions of $\{242 \mid 243\}$ khorēgia [= leadership of choral activities] and gumnasiarkhia [= leadership of athletic activities] and triêrarkhia [leadership of naval activities], they know all too well that the rich are in the position of leaders in the choral activities while the nonaristocrats are in the position of followers, and that the rich are in the position of leaders in the athletic and the naval activities while again the nonaristocrats are in the position of followers. And so, that is why the nonaristocrats feel entitled to take money for singing and running and dancing and sailing in ships. That way, they get money while the rich keep getting poorer and poorer.

Such is the slanted attitude of the Athenian Old Oligarch, who evidently thinks that the nonaristocrats were never really good enough to be leaders in choral and in athletic activities on a par with aristocrats. And, although the nonaristocrats could never even fully appreciate aristocratic activities, they spitefully passed a law that commercialized these activities. The Old Oligarch then goes on to highlight the irony he sees in the negative effects that such 
commercialization has created for the rich, whom he equates with the aristocrats. From his point of view, the Demos forces the rich to allow the poor to participate in choral and athletic activities that used to be restricted to aristocrats. And, to add insult to injury, the rich now have to pay for the participation of the poor. Thinking in this slanted context, the Old Oligarch equates such democratic practices as the awarding of per diem payments or of cash prizes at festivals with a doling out of silver to the poor. In this context, commercialization is a mark of nonaristocrats, not of aristocrats, and it leads to the professionalization of military service, of athletics, and even of theater.

In Athens during the classical period, then, the practice of putting a khorēgos 'chorusleader' in charge of khorēgia 'leading of a chorus' is a decidedly democratic practice, since this khorēgos in democratic Athens has become differentiated as a nonperformer whom the State appoints to produce and finance the performances of choruses in Athenian State Theater. ${ }^{69}$ That is what the Old Oligarch means, I argue, when he claims that the democratic State in Athens has stopped the 'musical' as well as the athletic performances of aristocrats: 'the Demos here [= at Athens] has stopped those [= the aristocrats] who practice athletics and who pursue

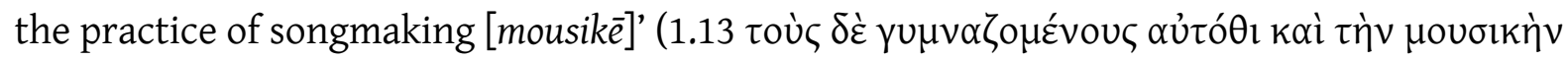

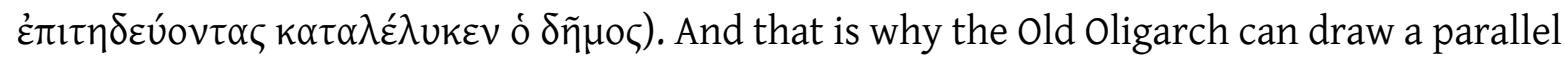
between an Athenian khoreggos and the Athenian gumnasiarkhos, who is appointed by the State to supervise the performances of athletes. $\{243 \mid 244\}$

This classical democratic Athenian model is a far cry from what we see attested in other cities during the preclassical or archaic period, where the khorēgos is simply the performing 'chorus leader' of the performing chorus. ${ }^{70}$ By contrast, the khorēgos is more of a 'chorus

\footnotetext{
${ }^{69}$ Calame 2001:43-46, 48-49; cf. PH 378.

${ }^{70}$ Calame 2001:43-46.
} 
producer' in the context of democratic Athens in the classical period, since the State has turned the chorus leader into a nonperformer.

So far, I have argued that the obloquy of the Old Oligarch is being directed specifically against institutional subsidizing, initiated by the democratic State, of expenses incurred in choral performance. Such subsidizing, I now argue further, is not in and of itself pertinent to what I maintain is the nonprofessional status of the rank-and-file chorus members themselves. For an earlier, more aristocratic pattern, we may reconstruct various different initiatives undertaken by various different aristocratic families in the production and financing of choral events-and, for that matter, of local athletic events as well. In the later, more democratic pattern, by contrast, the activities of producing and financing choral and athletic events were made the ultimate, although not the immediate, responsibility of the State. ${ }^{71}$ I propose that the eventual demise of the earlier pattern in the case of democratic Athens had to do with the obsolescence of the archaic choral tradition as represented by a figure like Stesichorus. I conclude, then, that "the scale and the virtuosity of choral performance at festivals and other such events would be different in aristocratic and democratic settings, and that Stesichorus represents a decidedly aristocratic setting., ${ }^{72}$

\section{The evolution of the choral poet-director}

Although I have disagreed with Burkert when he describes as itinerant professionals those who performed the singing and dancing in archaic choruses, I will now argue that such a description does in fact apply to the poets who composed the actual songs for the singing and dancing. A case in point is the poet Stesichorus, whose lifetime as we saw straddled the seventh and the sixth century BCE. Burkert says about this poet: "one might as well imagine a

\footnotetext{
${ }^{71}$ TCL 47.

${ }^{72}$ PH 362n124. Cf. Burnett 1988:129-147.
} 
traveling didaskalos selecting his chorus for training on the spot."73 I agree, but I need to stress that such a poet-director would ordinarily train local nonprofessionals for his choruses. A comparable $\{244 \mid 245\}$ description, I argue, applies to the prototypical figure of Homer as we have seen him represented in the Homeric Hymn (3) to Apollo: he is a wandering minstrel, an itinerant professional, who is represented in the act of interacting with the local chorus of the Delian Maidens. Homer acts as a poet-director for the Maidens as he cues them to perform their response to the perennial question: who is the best poet of them all? That is the force of the expression $\alpha \varphi^{\prime}$ ' $\mu \varepsilon \varepsilon^{\prime} \omega v$ at verse 171 of the Hymn: the Maidens are cued 'by me' to respond dialogically to a question 'about me'. ${ }^{74}$ Such is the mimesis of Homer by Homer about Homer, as performed for Homer by the Delian Maidens.

A comparable formulation applies to the figure of Alcman, whose lifetime as we saw can be dated back to the seventh century BCE: in the Spartan tradition, Alcman is represented as a Lydian foreigner who comes to Sparta as a poet-director of local choruses of young women (PMG 13a; also PMG 1 Scholion B; Velleius Paterculus 1.18.2; Aelian Varia Historia 12.50). It is relevant to cite here the Spartan ritual event known as $\tau \tilde{\omega} v \Lambda v \delta \tilde{\omega} v \pi 0 \mu \pi \eta$ ' the Procession of the Lydians' in connection with the cult of Artemis Orthia (Plutarch Life of Aristides 17.10). We may also compare a ritual event known as the 'Dance of the Lydian Maidens' at a festival of Artemis at Ephesus (Autocrates F 1 KA, by way of Aelian De natura animalium 12.9; Aristophanes Clouds 599-600). In this case, I argue that the term 'Lydian Maidens' designates a ritual role played by the local girls of Ephesus. ${ }^{75}$

\footnotetext{
${ }^{73}$ Burkert 1987:61n54.

${ }^{74}$ Relevant is the formulation of Bakker (2002:21) about the preverb apo: "In the case of verbs denoting speech, the addition of apo-turns the sensibility to context into an immediately dialogic sense: apo-logeomai 'speak in return', 'defend oneself against', apo-krinomai 'reason in return', 'answer'."

${ }^{75}$ PH 298-299.
} 
Another comparable formulation applies to a later figure, the poet Pindar, who as I already said flourished in the first half of the fifth century BCE. He is represented in his own compositions as a professional poet-director who comes as a xenos or 'guest-stranger' for the training of choruses to sing and dance in aristocratic settings:

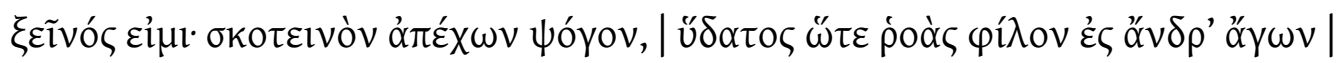

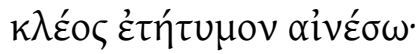

I am a guest-stranger [xenos]. Keeping away dark blame [psogos] and bringing genuine glory [kleos], like streams of water, to a man who is near and dear [philos], I will praise [aineîn] him.

Pindar Nemean 7.61-63

$\{245 \mid 246\}$ We may consider Pindar a professional to the extent that he must have received some form or forms of compensation from the rich and powerful families that commissioned the composition of his songs and the performance of these songs by local choruses. But such local choruses who performed such compositions, in line with the earlier aristocratic pattern, would have been comprised of nonprofessional performers. And the relationship of the nonprofessional chorus and a professional poet-director like Pindar can be expressed in terms of mimesis: the chorus as a group can be the impersonator or the actor, as it were, of the poetdirector. $^{76}$

The range of the mimesis performed by the chorus in Pindar's compositions extends far beyond the individual persona of the poet-director and the collective persona of the chorus as a chorus. For example, in the case of victory odes composed by Pindar and by other contemporary poets such as Simonides and Bacchylides, the speaking 'I' of the chorus is most

\footnotetext{
${ }^{76}$ PH 379.
} 
conventionally figured as a kōmos, that is, as a group of festive revelers. And this same speaking 'I' of the chorus or stylized kōmos can also make a mimesis of everyone and anyone who may be relevant to the act of praising the victor. The speaking characters, as it were, who take shape in the process of mimesis by the komos in a victory ode include such varied figures as (1) the poet himself in the role of the laudator or giver of praise, (2) the victorious athlete in the role of the laudandus or receiver of praise, (3) ancestors of the laudandus, and (4) heroes whose deeds in myth are praised along with the deeds of the laudandus.

As an example of roles enacted by the speaking 'I' of the chorus, I have already quoted the passage from Pindar's Nemean 7 where the 'I' speaks the role of the poet as laudator. As another example, I cite the passage in Pindar's Pythian 8 where the hero Amphiaraos is directly quoted (43 $\left.\tilde{\omega} \delta^{\prime} \varepsilon \tilde{i} \pi \varepsilon\right)$ as speaking from the dead (44-55).

There are many other kinds of mimesis to be found in victory odes. For example, the chorus can make a mimesis of a prototypical chorus of mythical singers and dancers embedded within the stylized kōmos of actual singers and dancers, as in the case of Ode 13 of the poet Bacchylides, a contemporary of Pindar. ${ }^{77}$ It can even happen that the chorus of a victory ode makes a mimesis of a chorus performing another genre of song, such as a hymn: Elroy Bundy has collected a variety of examples showing the "hymnal" function of expressions found in Pindar's victory odes that are cognate with expressions found even in the Homeric Hymns. ${ }^{78}$ $\{246 \mid 247\}$

\section{About the making of mimesis by the tragic chorus}

Such mimesis in the choral performance of compositions by poets like Pindar, Simonides, and Bacchylides can also be found in the choral performance of compositions by the poets of

\footnotetext{
${ }^{77}$ Power 2000.

${ }^{78}$ Bundy 1972:55-57.
} 
Athenian State Theater. I have in mind the poets of classical tragedy in particular, especially Sophocles and Euripides, who flourished in the second half of the fifth century BCE. As I will argue, the choruses of classical tragedy are just as mimetic as the choruses of victory odes.

In this connection, I plan to round out my essay by showing a particularly striking example of choral mimesis as we find it in a tragedy by Euripides, but first I need to outline some idiosyncrasies of the tragic chorus that make it distinct from other kinds of choruses.

\section{Idiosyncrasies of the chorus in Athenian tragedy}

Though the poets of Athenian tragedy can be described as professional poet-directors of nonprofessional choruses, the choruses that they directed were performing in decidedly democratic rather than aristocratic settings, the most prominent of which was the festival of the City Dionysia. It is the setting of the City Dionysia that distinguishes most clearly the choruses of what I have been calling Athenian State Theater, especially choruses of tragedy.

As in the case of the choral songs composed by the likes of Pindar, Simonides, and Bacchylides, a central feature of the choral songs composed by tragedians in classical Athens is the nonprofessionalism of the choral performers, but this nonprofessionalism needs to be contrasted with the professionalism of the actors playing roles differentiated out of the ranks of the chorus. ${ }^{79}$ In the medium of classical tragedy, the choral performers are reenacting an archetypal ensemble that is interacting with archetypal main characters in an archetypal world-characters acted out by the first, second, and third actors. ${ }^{80}$

The chorus in Athenian tragedy ordinarily performs by singing and dancing to the accompaniment of an aulos 'reed', while the actors ordinarily perform by declaiming their assigned verses, without musical accompaniment. Meanwhile, the differentiated function of a

\footnotetext{
${ }^{79}$ Cf. “Aristotle," Problems 19.15, and the comments in PH 343.

${ }^{80}$ TCL 45-46. I also analyze there the initiatory function of choral performance.
} 
performing chorus $\{247 \mid 248\}$ leader is further differentiated by another split in functions, with a more distinct first actor on one hand and a less distinct chorus leader on the other. This development is represented in the story of the primordial dramaturge Thespis, who is said to have invented the first actor. ${ }^{81}$ The dialogue between the Thespian first actor and the chorus leader manifests a differentiation of the dialogue between an undifferentiated chorus leader and the chorus, and the evolution of the second actor and third actor can be explained in terms of further splits in function. ${ }^{82}$

The chorus represents a mediating principle between the main characters of the archetypal there-and-then and the audience of the historical here-and-now. The chorus reacts both as if they were the audience itself and as if they were eyewitness contemporaries of the archetypal main characters. The members of the chorus, who sang and danced the roles of groups such as old men or young girls, are "on the scene" in the world of the archetypal main characters. ${ }^{83}$

From the standpoint of tragic action, the focus of attention is on the archetypal main characters, played by the actors. The main characters and their experiences are central while the chorus, as eyewitness, is marginal. Although the chorus is emotionally involved in the experiences of the main characters, it also maintains an emotional distance by being marginal to the drama of the tragic action and by being central to the ritual that engages with the audience. What is passive pathos or action experienced by the main characters within the world of tragedy is active dräma, that is, sacrifice and the performance of ritual, from the standpoint of the outer world that frames it. This outer world is constituted by the audience of the theater, who

\footnotetext{
${ }^{81}$ Pickard-Cambridge 1968:130-131.

${ }^{82}$ PH 378.

${ }^{83}$ TCL 49.
} 
become engaged in the drāma through the intermediacy of the chorus and who thereby participate in the inner world that is the pathos of any main character..$^{84}$

In this sense, the pathos experienced by a main character in drama is a primal 'ordeal' while the reactive pathos experienced by the audience-and mediated by the chorus - may be translated simply as 'emotion'. Such a distribution of translations for pathos, that is, 'ordeal' for the main characters and 'emotion' for the audience, seems pervasively workable in a reading of Aristotle's Poetics. One commentator has put it nearly this same way, in defining Aristotle's concept of pathos as a 'misfortune' on the objective level and an 'emotion' on the subjective level. ${ }^{85}\{248 \mid 249\}$

\section{The Delian Maidens as models of theatrical mimesis}

What I have just reconstructed as a mediation of pathos by the chorus of classical tragedy corresponds to a description of mimesis that we find in an essay by Lucian. As I will argue, Lucian's description is essential for understanding the role of the Delian Maidens as models of theatrical mimesis. Here is the relevant passage:

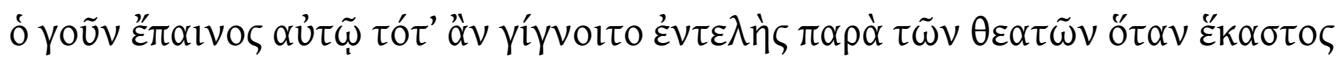

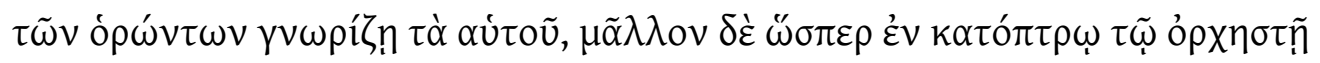

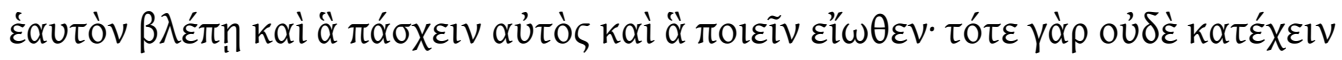

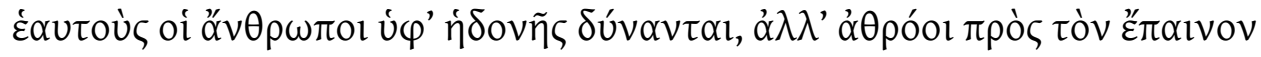

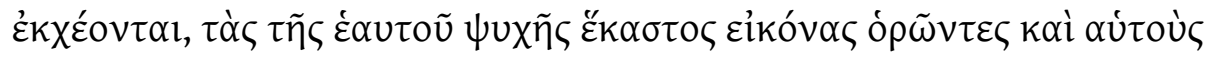

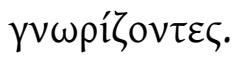

\footnotetext{
${ }^{84} \mathrm{PH} 388$.

${ }^{85}$ Lucas 1968:134.
} 
So, he [= the dancer $]$ would get complete approval from the spectators only when everyone viewing the spectacle recognizes those things that they can identify with their own selves-or, to put it another way, only when the people who are looking at the dancer recognize their own selves and recognize the things they are used to experiencing [paskhein] or doing [poiein] as if they were seeing themselves in a mirror. When this happens, people get so much pleasure out of it that they can barely contain themselves, bursting into unanimous expressions of approval, since they all see images of their own souls and recognize themselves.

\section{Lucian On dance 81}

As Lucian adds, the spectators that have seen such a spectacle of a perfectly executed dance can leave the theater with a sense of having participated in a perfect theatrical experience: kai

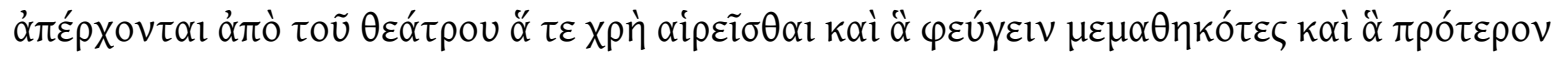

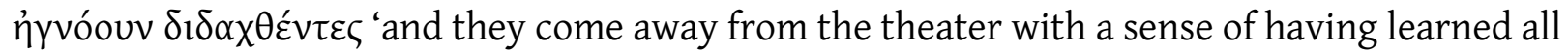
the things that they should embrace and all the things they should avoid, having learned things that they had not known before' (On dance 81). And such a perfectly executed dance, as we see in the present context and elsewhere as well in Lucian's essay, is a matter of mimesis (On dance 82: $\tau \tilde{\eta} \varsigma \mu \uparrow \mu \eta ́ \sigma \varepsilon \omega \varsigma)$. Further, it is a mimesis of experienced emotion, pathos (On dance

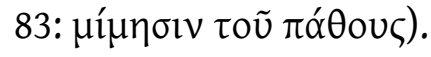

Using this passage from Lucian, Peponi has compared the psychology of experiencing such pathos, such emotion, with the psychology of experiencing the performance of the Delian Maidens:

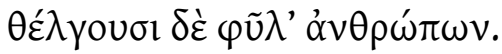

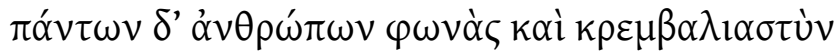




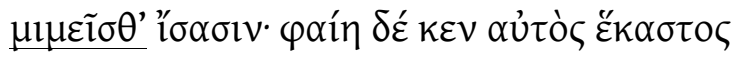

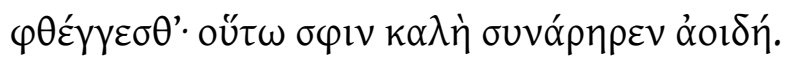

$\{249 \mid 250\}$ They [= the Delian Maidens] enchant all different kinds of humanity.

All humans' voices and rhythms

they know how to reenact [mimeîsthai]. And each single person would say that his own voice was their voice. That is how their beautiful song has each of its parts fitting together [sun-arariskein] in place.

Homeric Hymn (3) to Apollo 159-164

Taking her cue from the use of the words paskhein 'experience' and pathos 'experienced emotion' in the passage I have quoted from Lucian's essay, Peponi says that the choral performance of the Delian Maidens and the reaction of the audience are "mutually empathetic." ${ }^{16}$ Accordingly, she speaks of a choral "aesthetics of empathy." ${ }^{17}$

I agree with this formulation, and I agree at least in part with the explanation that follows it: "through their excellence the choral performers achieve a holistic representation of the audience; in turn, the enchanted audience empathizes to such a degree that they attend as

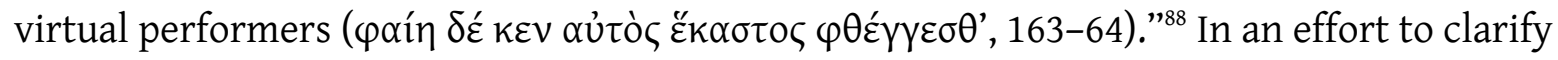
further, I propose that the various people in the varied audience attending a performance by the Delian Maidens are not just virtual performers: they are potential performers in their own

\footnotetext{
${ }^{86}$ Peponi 2009:67. She describes the audience's reaction as a "spectatorship."

${ }^{87}$ Peponi 2009:60.

${ }^{88}$ Peponi 2009:67.
} 
right, because it is their own various choral traditions that the Delian Maidens can perform by virtue of their divine status as models of all varieties of choral performance.

\section{The Delian Maidens as models of choral performance in tragedy}

In the Homeric Hymn to Apollo, there is no direct indication of the kinds of choral performance that the Delian Maidens perform at the festival of the Delia on the island of Delos. But there are indirect indications to be found in other sources. As we are about to see, two choral genres that actually typify the Delian Maidens, the hymn and the paean, can become models for imitation in the choral performance of tragedy. And that is because mimesis, as we have already seen, can in fact extend from one genre to another, as in the imitation of a choral hymn by a choral victory ode.

When Thucydides (3.104.5) refers to the Delian Maidens as a chorus of local 'women', he is simply following his usual practice of downplaying details of myth and ritual. As I have already argued, however, the Delian Maidens who perform at the festival of the Delia in Delos are simultaneously Muses as well as real-life performers participating in a chorus of local $\{250 \mid 251\}$ girls or women, since the role of divinity can be appropriated by participants in a chorus during choral performance. That is to say, the Delian Maidens as a local female chorus can reenact the Delian Maidens as local Muses. ${ }^{89}$

What is essential for now is that even Thucydides accepts the idea that the chorus of Delian Maidens with whom Homer himself interacted in the Homeric Hymn to Apollo is somehow a prototype for the choruses that perform at the Delia in historical times. Relevant is the wording of Thucydides where he makes these further remarks about the performances of choruses at the Delia (3.104.6): 'So much for the evidence given by Homer concerning the fact

\footnotetext{
${ }^{89}$ See also Calame 2001:30, 104, 110
} 
that there was even in the remote past a great coming together and festival [heortē] at Delos; later on, the islanders [nēsiōtai] and the Athenians continued to send song-and-dance groups

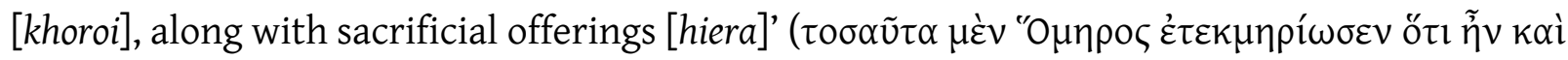

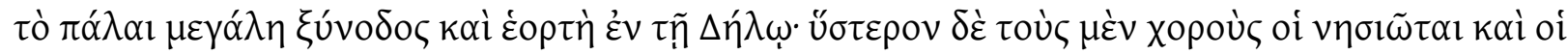

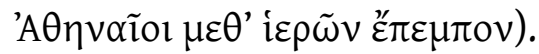

For city-states to send their local choruses to perform at festivals like the Delia was considered to be part of a 'sacrifice', as conveyed by the word hiera 'sacrificial offerings' in the description I just quoted from Thucydides. ${ }^{90}$ In fact, as I show in a study of epigraphical and literary sources dating especially from the fourth century BCE, a traditional word for 'festival' was thusia, which literally means 'sacrifice'. ${ }^{91}$

There is a most relevant attestation of both these words, hiera 'sacrificial offerings' and thusia 'sacrifice, festival', in an account concerning the celebration of the Delia at Delos in the glory days of the Athenian empire. This account, which gives a full-blown description of the magnificent spectacle of choral performances at the Delia, comes from Plutarch's Life of Nikias (3.5-7):

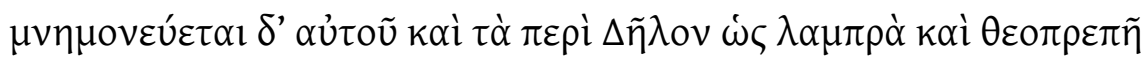

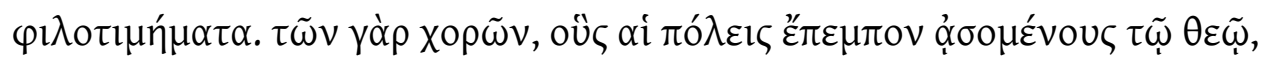

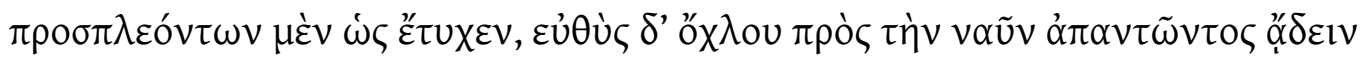

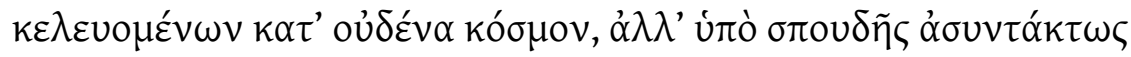

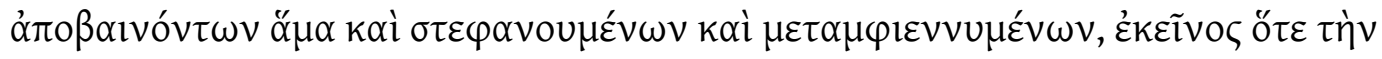

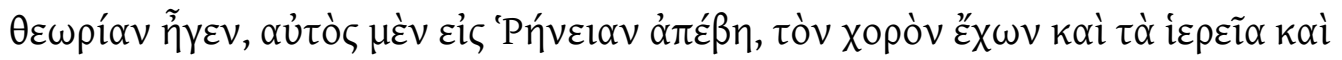

\footnotetext{
${ }^{90}$ Relevant also is the expression anagein khorous 'bring choruses' in Thucydides 3.104.3, since the verb anagein, with khoroi as its direct object, "seems to describe a typically religious 'contribution'." So Kowalzig 2007:71.

${ }^{91}$ PR 40-41, 48-49, 52-53, 83.
} 


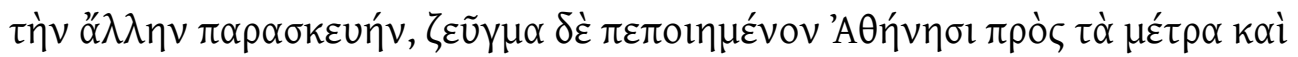

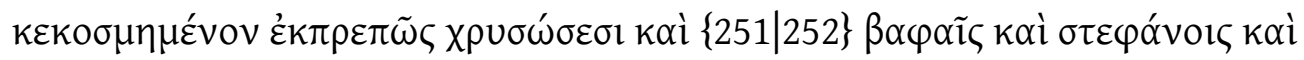

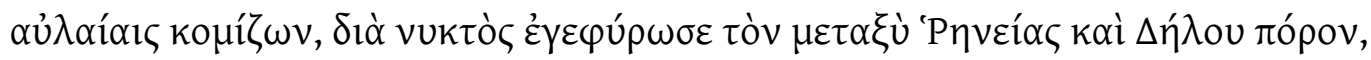

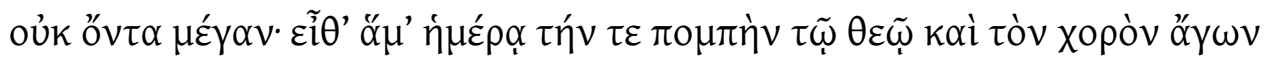

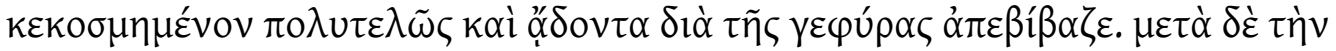

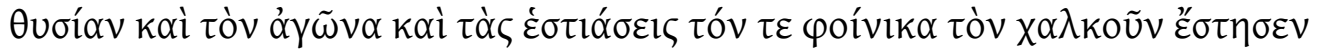

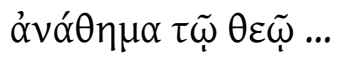

Nikias is remembered for his ambitious accomplishments with regard to Delos accomplishments most spectacular in all their splendor and most worthy of the gods in all their magnificence. Here is an example. The choral groups [khoroi] that cities used to send (to Delos) for the performances of songs sacred to the god (Apollo) used to sail in (to the harbor of Delos) in a haphazard fashion, and the crowds that would gather to greet the ship used to start right away to call on the performers to start singing their song. There was no coordination, since the performers were still in the process of disembarking in a rushed and disorganized way, and they were still putting on their garlands and changing into their costumes. But when he [= Nikias] was in charge of the sacred voyage [theōria] (to Delos), he first took a side trip to the island of Rheneia, bringing with him the choral group [khoros] and the sacrificial offerings [hiereia] and all the rest of the equipment. And he brought with him a bridge that had been made in advance, back in Athens, to fit the present occasion, and this bridge was most splendidly adorned with golden fixtures, with dyed colors, with garlands, with tapestries. Overnight, he took this bridge and spanned with it the strait 
between Rheneia and Delos - not a very great distance. ${ }^{92}$ Then, come daylight, he led the procession in honor of the god and brought across the bridge to their destination the performers of the choral group [khoros], who were outfitted most magnificently and were all along performing their song. Then, after the sacrifice [thusia] and after the competition [agōn] and after the feasting, he set up as a dedication to the god the (famous) bronze palm tree ...

Plutarch Life of Nikias 3.5-7

This description by Plutarch, composed half a millennium after the events described, still features the essential ritual concepts of hier(ei)a 'sacrificial offerings' and thusia 'sacrifice, festival'.

And we know that the practice of sending choral groups to perform at Delos, as attested in this narrative about events taking place in the second half of the fifth century, was in full bloom already in the first half of the fifth century BCE, when choruses sang and danced choral songs composed by such master poets as Simonides and Pindar. The primary evidence comes from surviving fragments of their choral songs. ${ }^{93}\{252 \mid 253\}$

In one of these choral songs, composed by Simonides to be performed at the Delia in Delos, the Delian Maidens themselves are actually called upon to shout a choral cry (F 55a3):

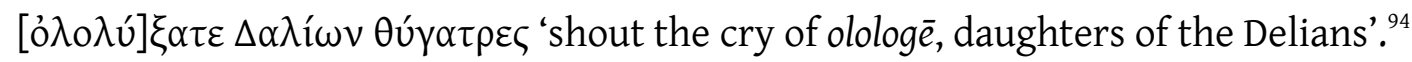

The majority of these choral songs performed in honor of Apollo can be identified as paianes 'paeans'.$^{95}$ And there is an explicit reference to such a paean as chorally performed by the Delian Maidens themselves at Delos:

\footnotetext{
${ }^{92}$ This spanning of the strait between the islands of Rheneia and Delos must have been interpreted as the ritual equivalent of the earlier chaining together of the two islands by Polycrates, as narrated by Thucydides 3.104.2.

${ }^{93}$ This evidence has been surveyed and analyzed by Kowalzig 2007 ch. 2.

${ }^{94}$ Kowalzig 2007:64-66
} 


\author{
$\pi \alpha \imath \tilde{\alpha} v \alpha \mu \dot{\varepsilon} v \Delta \eta \lambda \lambda^{\prime} \alpha ́ \delta \varepsilon \varsigma$ \\ $<v \alpha \tilde{\omega} v>\dot{v} \mu \nu o \tilde{v} \sigma^{\prime} \dot{\alpha} \mu \varphi \grave{i} \pi u ́ \lambda \alpha \varsigma$

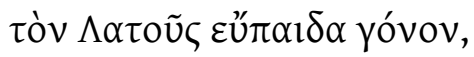

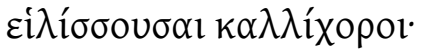

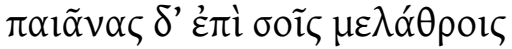

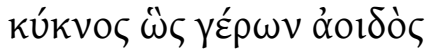 \\ $\pi \circ \lambda_{\imath} \tilde{\alpha} v \varepsilon \dot{\varepsilon} \kappa \gamma \varepsilon v u ́ \omega v$

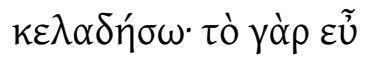

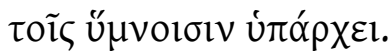

A paean do the Delian Maidens

sing as a humnos around the temple gates,

singing (Apollo) the true child of Leto

as they swirl, and they have such a beautiful khoros.

I too, singing paeans at your palace,

aged singer that I am, like a swan,

from my graybearded throat,

will send forth a cry. For whatever is real

has a place to stay in my humnoi.

Euripides Herakles 687-695 96

\footnotetext{
${ }^{95}$ Kowalzig 2007:57.

${ }^{96}$ For an incisive commentary on this passage, see Henrichs 1996:55-56.
} 
As we can see from this reference in a choral song composed by Euripides, the Delian Maidens are described as performing the kind of choral song that is known as the paian 'paean', which is equated here with the performing of a humnos.

The equation is made clear in the syntax of the wording, which can be analyzed in two steps. First, the verb humnein 'sing a humnos' takes as its inner object the song that is sung as a humnos, and this song is in fact a paian 'paean'. Second, the same verb humnein takes as its outer object the name of the god Apollo, who is both the object of praise and the subject of the song that is the humnos. When I use the expression subject of the song here, I mean the subject matter, not the grammatical subject. In the grammar of $\{253 \mid 254\}$ a humnos as a song, the divinity that figures as the subject of the song is in fact the grammatical object of the verb of singing the song.

The fact that the chorus of Euripides' Herakles refers to its choral performance as both a humnos 'hymn' and a paian 'paean' is a reference to its ongoing mimesis of two different kinds of choral genre. At the moment of performance, we see a fusion of the two distinct genres. Such fusion corresponds to the term used by Plato, theatrokratia, in describing what he thinks is the confusion of genres in the theatrokratia of democratic Athenian State Theater. As we have seen, two of the five genres he mentions in his list of confused genres are the humnos and the paian (Laws 3.700b).

In describing the reference in the Herakles of Euripides to the performance of the Delian Maidens, I used the term ongoing mimesis, in the sense that the actual performance by the chorus of the Herakles is making a mimesis of an idealized performance by the chorus of the Delian Maidens at the festival of the Delia at Delos. I repeat my earlier formulation, that these Maidens "are presented in the Hymn as archetypes meant to be reenacted in the local ritual context of real choral performances at Delos-in which context the choral participants would 
be equated, for the ritual moment, with the archetypal Maidens." ${ }^{97}$ There is another example of such ongoing mimesis in Euripides Hekabe 462-465, where we see another such reference to the performance of the Delian Maidens at Delos. These two references to the performing Delian Maidens, as well as other such references to the performances of other choruses, have been analyzed by Henrichs as examples of "choral projection." ${ }^{98}$ Here is the wording of his overall formulation:

Choral projection occurs when Sophoclean and Euripidean choruses locate their own dancing in the past or the future, in contrast to the here and now of their immediate performance, or when choruses project their collective identity onto groups of dancers distant from the concrete space of the orchestra and dancing in the allusive realm of the dramatic imagination. ${ }^{99}$

I agree with this formulation, adding that we need to highlight (1) the singing as well as the dancing of the chorus and (2) the ritual context of the "distant" choral performance, which is the point of reference for the actual choral performance.

In the case of the Herakles of Euripides, which refers to a "distant" choral performance, at Delos, of a paean that is also a hymn, I note that the $\{254 \mid 255\}$ ritual context of such choral performance is attested in a paean (Paean 12) composed by Pindar to be performed at Delos by a chorus sent there from the island state of Naxos (line 2, $[\mathrm{N \alpha}] \xi \mathrm{o}^{\theta} \mathrm{\varepsilon v}$ ), and that the context of this performance of a paean is highlighted as a thusia 'sacrifice' (also line 2, $\theta v \sigma i[\alpha]) .{ }^{100}$ In this same paean by Pindar (Paean 12), performers belonging to a local female chorus, who are

\footnotetext{
${ }^{97}$ PP 56; quoting this formulation, Henrichs (1996:58n35) adds: “This description also fits the relationship of Delian Maidens ('archetypes') and tragic chorus ('real chorus-members') in Herakles.

${ }^{98}$ Henrichs 1996:55-56.

${ }^{99}$ Henrichs 1996:27.

${ }^{100}$ Kowalzig 2007:60.
} 
described as enkhōriai 'the local ones', are said to be shouting a ritual cry (line 19,

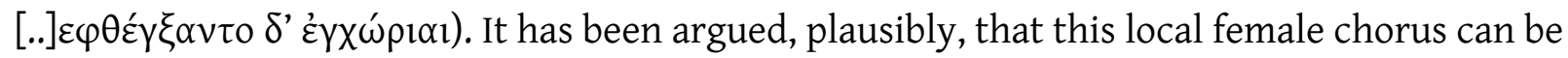
identified with the Delian Maidens. ${ }^{101}$ And I note that this local female chorus is evidently interacting with the visiting male chorus sent from the island state of Naxos.

The precise nature of such choral interaction is most likely to be mimetic: for example, the visiting male chorus may be reenacting the performance of the local Delian Maidens ${ }^{102}$ much as the visiting rhapsode Homer is reenacting the performance of the Maidens in the Homeric Hymn to Apollo. ${ }^{103}$

\section{Conclusions}

The reference to the Delian Maidens in the Homeric Hymn (3) to Apollo as models of mimesis 'reenactment, imitation' (verb mimeîsthai at verse 163) is saying something that is fundamentally true about choral performance in general, which as we know from the surviving textual evidence is highly mimetic. And this mimeticism is fully brought to life in the reference to the Delian Maidens by the chorus in the Herakles of Euripides.

This formulation about the mimeticism of choral performance applies to rhapsodic performance as well: that medium too is highly mimetic, as we see from the interaction of Homer with the Delian Maidens in the Homeric Hymn to Apollo. The figure of Homer reenacts the Maidens by quoting what they say, which is said not in their own choral medium but in the rhapsodic medium of the Hymn. ${ }^{104}$ Thus the medium of rhapsodic performance shows that it can make a mimesis of the medium of choral performance as exemplified by the Delian

\footnotetext{
${ }^{101}$ Kowalzig 2007:66-67.

${ }^{102}$ Kowalzig 2007:71 argues that "the Naxians performing Paean 12 ... themselves become, as it were, the Deliades."

${ }^{103}$ On the re-enacting of mythical performances of female khoroi by way of the ritual performances of male khoroi, see again Power 2000 on Bacchylides Ode 13; also Nagy 2011 (forthcoming).

${ }^{104}$ HC 206.
} 
Maidens, who are the absolute models of choral mimesis. And, this way, Homer demonstrates that he is the absolute master of rhapsodic mimesis. $\{255 \mid 256\}$

In this connection, I see no need to set up a dichotomy between what has been called "nondramatic lyric" as performed by such choruses as we see in Song 1 of Alcman and "dramatic lyric" as performed by the choruses of Athenian State Theater. I think that both these kinds of choral lyric are "dramatic" or "theatrical," in the sense that both these kinds of choral lyric are in fact mimetic. And the mimesis that we see in these two kinds of choral lyric, as I argued from the beginning, is an act of mediation between solo and choral performance.

In the case of classical drama, as I have argued, such mediation between solo and choral performance bridges the gap between characters in an archetypal past and the citizens of Athens in the present, whose attendance at Athenian State Theater was understood to be an act of civic participation. The nonprofessional chorus could mediate between the professional actors who represented the archetypal characters on the one hand and, on the other, the body of Athenian citizens who participated in the dramatic festivals of their city by virtue of attending Athenian State Theater. The members of the chorus who sang and danced the roles of participants in the mythical world of the archetypal past were also participating in the ritual world of the Athenian dramatic festivals, thus mediating between the actors and the citizens in attendance. Such mediation, I conclude, is the essence of mimesis. ${ }^{105}$

\section{Bibliography}

Allen, T. W. 1912. ed. Homeri Opera V (Hymns, Cycle, fragments). Oxford. Aloni, A. 1989. L'aedo e i tiranni: Ricerche sull'Inno omerico ad Apollo. Rome.

\footnotetext{
${ }^{105}$ Since the writing of this piece, I have modified slightly my thinking about the marginalization of the chorus in the action of tragedy, in the light of recent work published by U. S. Dhuga. Also, I have been working on a project that focuses on the specialization of actors as virtuoso singers in tragedies of Euripides.
} 
BA. See Nagy 1979.

Bakker, E. J. 1997. Poetry in Speech. Orality and Homeric Discourse. Ithaca NY.

--_. 2002. “The Making of History: Herodotus' historiēs apodexis.” Brill's Companion to Herodotus (ed. E. J. Bakker, I. J. F. De Jong, H. van Wees) 3-32. Leiden.

--_. 2005. Pointing at the Past: From Formula to Performance in Homeric Poetics. Washington DC.

Barrett, W. S., ed. 1964. Euripides: Hippolytus. Oxford.

Bundy, E. L. 1972. “The 'Quarrel between Kallimachos and Apollonios' Part I: The Epilogue of Kallimachos's 'Hymn to Apollo'.” California Studies in Classical Antiquity 5:39-94.

-_-. 1986 [1962]. Studia Pindarica. Berkeley and Los Angeles CA.

Burkert, W. 1979. "Kynaithos, Polycrates, and the Homeric Hymn to Apollo." Arktouros: Hellenic Studies Presented to B. M. W. Knox (ed. G. W. Bowersock, W. Burkert, and M. C. J. Putnam) 53-62. Berlin.

- - . 1987. "The Making of Homer in the Sixth Century B.C.: Rhapsodes versus Stesichorus." In: Papers on the Amasis Painter and His World, ed. M. True, C. Hudson, A. P. A. Belloli, B. Gilman, et al. 43-62. Malibu, CA.

Burnett, A. 1988. “Jocasta in the West: The Lille Stesichorus.” Classical Antiquity 7:108-154.

Calame, C. 1977. Les choeurs de jeunes filles en Grèce archaïque. Vol. 1, Morphologie, fonction religieuse et sociale. Vol. 2, Alcman. Filologia e critica 20-21. Rome.

--C. Choruses of Young Women in Ancient Greece: Their Morphology, Religious Role, and Social Function (tr. D. Collins and J. Orion). ed. 2. Lanham MD.

--—. 2005. Masks of Authority: Fiction and Pragmatics in Ancient Greek Poetics (tr. P. M. Burk). Ithaca NY.

-_-. 2007. "Mythos, musische Leistung und Ritual am Beispiel der melischen Dichtung." Literatur und Religion I. Wege zu einer mythisch-rituellen Poetik bei den Griechen (ed. A. Bierl, R. Lämmle, K. Wesselmann; Basiliensia - MythosEikonPoiesis, vol. 1.1) 179-210. Berlin / New York.

- - . 2009. "Referential Fiction and Poetic Ritual: Towards a Pragmatics of Myth (Sappho 17 and Bacchylides 13)." Trends in Classics 1:1-17. 
Chantraine, P. 2009. Dictionnaire étymologique de la langue grecque: histoire des mots (ed. J. Taillardat, O. Masson, and J.-L. Perpillou), with a supplement Chroniques d'étymologie grecque 1-10 (ed. A. Blanc, Ch. de Lamberterie, and Jean-Louis Perpillou). Paris. Abbreviated DELG.

Clay, D. 1991. “Alcman’s Partheneion." Quaderni Urbinati di Cultura Classica 39:47-67.

---. 2004. Archilochos Heros: The Cult of Poets in the Greek Polis. Washington DC and Cambridge MA.

Clay, J. S. 1989. The Politics of Olympus: Form and Meaning in the Major Homeric Hymns. Princeton.

---. 1997. "The Homeric Hymns." A New Companion to Homer (ed. I. Morris and B. Powell) 489507. Leiden.

Colbeaux, M.-A. 2005. Raconter la vie d'Homère dans l'antiquité. Édition commentée du traité anonyme, "Au sujet d'Homère et d'Hésiode, de leurs origines et de leur joute," e de la "Vie d'Homère" attribué à Hérodote. Dissertation, Université Charles de Gaulle - Lille III.

Collins, D. 2004. Master of the Game: Competition and Performance in Greek Poetry. Washington DC and Cambridge MA.

Currie, B. 2005. Pindar and the Cult of Heroes. Oxford.

De Martino, F. 1982. Omero agonista in Delo. Brescia.

Fearn, D. 2003. "Mapping Phleious: Politics and myth-making in Bacchylides 9." Classical Quarterly 3:347-367.

-_- Bacchylides: Politics, Performance, Poetic Tradition. Oxford.

---, ed. 2010. Aegina: Contexts for Choral Lyric Poetry. Myth, History, and Identity in the Fifth Century BC. Oxford.

Ferrari, G. 2008. Alcman and the Cosmos of Sparta. Chicago.

Figueira, T. J. 1981. Aegina, society and politics. New York.

--_. 1985a. "The Theognidea and Megarian Society." Theognis of Megara: Poetry and the Polis (ed. T. J. Figueira and G. Nagy) 112-158. Baltimore.

---. 1985b. "Chronological Table: Archaic Megara, 800-500 B.C." Theognis of Megara: Poetry and the Polis (ed. T. J. Figueira and G. Nagy) 261-303. Baltimore. 
---. 1991. Athens and Aigina in the age of imperial colonization. Baltimore.

-—-. 1993. Excursions in epichoric history: Aeginetan essays. Lanham MD.

Frame, D. 2009. Hippota Nestor. Washington DC.

GM. See Nagy $1990 b$.

Goff, B. 1990. The Noose of Words: Readings of Desire, Violence and Language in Euripides' Hippolytus. Cambridge.

Graziosi, B. 2002. Inventing Homer: The Early Reception of Epic. Cambridge.

HB. See Nagy 2009.

HC. See Nagy 2008/2009.

Henrichs, A. 1996. "Dancing in Athens, Dancing in Delos: Some Patterns of Choral Projection in Euripides." Philologus 140:48-62.

Herington, J. 1985. Poetry into Drama: Early Tragedy and the Greek Poetic Tradition. Berkeley.

Hornblower, S. 1991. A Commentary on Thucydides. I (Books I-III). Oxford.

HPC. See Nagy 2009/2010.

HQ. See Nagy 1996b.

HR. See Nagy 2003.

HTL. See Nagy 2004c.

Janko, R. 1982. Homer, Hesiod, and the Hymns: Diachronic Development of Epic Diction. Cambridge.

Koller, H. 1956. "Das kitharodische Prooimion: Eine formgeschichtliche Untersuchung." Philologus 100:159-206.

Kowalzig, B. 2007. Singing for the gods: Performances of myth and ritual in archaic and classical Greece. Oxford.

Larson, J. 2001. Greek Nymphs: Myth, Cult, Lore. Oxford.

Larson, S. 2000. "Boiotia, Athens, the Peisistratids, and the $<<$ Odyssey >>'s Catalogue of Heroines." Greek Roman and Byzantine Studies 41:193-222. 
Loraux, N. 1998. Mothers in Mourning, with the essay "Of Amnesty and its Opposite" (tr. C. Pache). Ithaca $\mathrm{NH}$.

Lord, A. B. 1960. (ed. 2; 2000. eds / intro. S. Mitchell and G. Nagy [vii-xxix]). The Singer of Tales. Harvard Studies in Comparative Literature 24. Cambridge MA.

Lucas, D. W., ed. 1968. Aristotle: Poetics. Oxford.

Maehler, H. 1982. ed. Die Lieder des Bakchylides I. Die Siegeslieder II. Kommentar. Leiden.

Martin, R. P. 1997. “Similes and Performance." Written Voices, Spoken Signs (ed. E. Bakker and A. Kahane) 138-166. Cambridge MA.

---. 2000a. "Wrapping Homer Up: Cohesion, Discourse, and Deviation in the Iliad." Intratextuality: Greek and Roman Textual Relations (ed. A. Sharrock and H. Morales) 43-65. Oxford.

-- . 2000b. "Synchronic Aspects of Homeric Performance: The Evidence of the Hymn to Apollo." In Una nueva visión de la cultura griega antigua hacia el fin del milenio (ed. A. M. González de Tobia) 403-432. La Plata.

Meyer, H. 1933. Hymnische Stilelemente in der frühgriechischen Dichtung. Dissertation Köln.

Miller, A. M. 1986. From Delos to Delphi: A Literary Study of the Homeric Hymn to Apollo. Leiden.

Most, G. W. 2006a/b. ed. and transl. Hesiod: Theogony, Works and Days, Testimonia / The Shield, Catalogue of Women, Other Fragments. Cambridge MA.

Muellner, L. 1996. The Anger of Achilles: Mênis in Greek Epic. Ithaca NY.

Nagy, G. 1979. The Best of the Achaeans: Concepts of the Hero in Archaic Greek Poetry (ed. 2. with new introduction 1999). Baltimore MD

-—-. 1982. "Hesiod.” Ancient Writers (ed. T. J. Luce) 43-73. New York.

-- - 1985. “Theognis and Megara: A Poet's Vision of His City.” Theognis of Megara: Poetry and the Polis (ed. T. J. Figueira and G. Nagy) 22-81. Baltimore MD.

- - 1989. Foreword to The Language of Heroes, by R. P. Martin. ix-xi. Ithaca, NY.

-- . 1990a. Pindar's Homer: The Lyric Possession of an Epic Past. Baltimore. <<http://www.press.jhu.edu/books/nagy/PHTL/toc.html>> (1997).

-- . 1990b. Greek Mythology and Poetics. Ithaca NY. 
---. 1992. "Mythological Exemplum in Homer." In Innovations of Antiquity, ed. R. Hexter and D. Selden. 311-331. London.

---. 1994/1995a "Transformations of Choral Lyric Traditions in the Context of Athenian State Theater." Arion 3:41-55. Hereafter abbreviated as TCL.

---. 1994/1995b. “Genre and Occasion." MHTIL: Revue d'anthropologie du monde grec ancien 910:11-25.

--_. 1996a. Poetry as Performance: Homer and Beyond. Cambridge.

---. 1996b. Homeric Questions. Austin TX.

---. 2000. "Dream of a Shade": Refractions of Epic Vision in Pindar's Pythian 8 and Aeschylus' Seven against Thebes. Harvard Studies in Classical Philology 100:97-118.

---. 2002. Plato's Rhapsody and Homer's Music: The Poetics of the Panathenaic Festival in Classical Athens. Cambridge MA / Athens.

--- . 2003. Homeric Responses. Austin TX.

---. 2004a. "L'aède épique en auteur: la tradition des Vies d'Homère." Identités d'auteur dans l'Antiquité et la tradition européenne (ed. C. Calame, and R. Chartier) 41-67. Grenoble.

---. 2004b. "Transmission of Archaic Greek Sympotic Songs: From Lesbos to Alexandria." Critical Inquiry 31:26-48.

---. 2004c. Homer's Text and Language. Urbana / Chicago IL.

---. 2005a. "The Epic Hero." A Companion to Ancient Epic (ed. J. M. Foley) 71-89. Oxford.

---. 2005b. "The Epic Hero."

http://chs.harvard.edu/publications.sec/online_print_books.ssp/gregory_nagy_the_epi c/bn_u_tei.xml_5

---. 2006. "Homer's Name Revisited." La langue poétique indo-européenne (ed. G.-J. Pinault and D. Petit; Actes du Colloque de travail de la Société des Études Indo-Européennes [Indogermanische Gesellschaft / Society for Indo-European Studies], Paris, 22-24 octobre 2003; Collection linguistique de la Société de Linguistique de Paris, t. 91) 317330. Leuven and Paris.

---. 2007a. "Did Sappho and Alcaeus ever meet?" Literatur und Religion I. Wege zu einer mythisch-rituellen Poetik bei den Griechen (ed. A. Bierl, R. Lämmle, and K. Wesselmann; 
Basiliensia - MythosEikonPoiesis, vol. 1.1) 211-269. Berlin / New York. Second edition 2009 online at chs.harvard.edu.

---. 2007b. "Lyric and Greek Myth." The Cambridge Companion to Greek Mythology (ed. R. D. Woodard) 19-51. Cambridge.

-- . 2008/2009. Homer the Classic. Cambridge MA and Washington DC. The 2008 online version is available at chs.harvard.edu. The 2009 printed version is distributed by Harvard University Press.

-- . 2009. "Hesiod and the Ancient Biographical Traditions." Brill Companion to Hesiod (ed. F. Montanari, A. Rengakos, and Ch. Tsagalis) 271-311. Leiden.

-- - 2009/2010. Homer the Preclassic. Berkeley / Los Angeles CA. The 2009 online version is available at chs.harvard.edu. The 2010 printed version is published by the University of California Press.

---. 2010. "Asopos and his multiple daughters: Traces of preclassical epic in the Aeginetan Odes of Pindar." In Fearn 2010.

- - . 2011. "A second look at the poetics of reenactment in Ode 13 of Bacchylides." Forthcoming.

Papadopoulou, I. 2004. "Poètes et (Philo)sophoi: Pour une archéologie de la mimesis." Revue de Philosophie ancienne 24:3-16.

Parry, A. 1971. ed. The Making of Homeric Verse: The Collected Papers of Milman Parry. Oxford.

Peponi, A. E. 2009. "Choreia and Aesthetics in the Homeric Hymn to Apollo: The Performance of the Delian Maidens (lines 156-64)," Classical Antiquity 28:39-70.

Pertusi, A. 1955. ed. Scholia vetera in Hesiodi Opera et Dies. Milano.

Petrović, I. 2011a. "Greek hymns: The true never-ending stories.” Forthcoming.

--_. 2011b. "Rhapsodic hymns and epyllia." Forthcoming.

PH. See Nagy 1990a.

Pickard-Cambridge, A. 1968. The Dramatic Festivals of Athens. 2nd ed., rev. J. Gould and D. M. Lewis. Cambridge.

Power, T. 2000. “The Parthenoi of Bacchylides 13." Harvard Studies in Classical Philology 100:67-81. 
PP. See Nagy 1996 a.

Propp, V. Ja. 1975. “The Russian Folk Lyric.” In Down Along the River Volga: An Anthology of Russian Folk Lyrics, with an Introductory Essay by V. Ja. Propp. Trans. R. Reeder. 1-73. Philadelphia.

Pucci, P. 1977. “Euripides: The Monument and the Sacrifice.” Arethusa 10:165-195.

Rhodes, P. J. 1981. A Commentary on the Aristotelian Athenaion Politeia. Oxford.

Rotstein, A. 2004. “Aristotle, Poetics 1447a13-16 and Musical Contests.” Zeitschrift für Papyrologie und Epigraphik 149:39-42.

Rutherford, I. C. 2001. Pindar's Paeans: A Reading of the Fragments with a Survey of the Genre. Oxford.

Saussure, F. de. 1916. Cours de linguistique générale. Critical ed. 1972 by T. de Mauro. Paris.

Seaford, R., ed. 1984. Euripides: Cyclops. Oxford.

Segal, C. 1982. Dionysiac Poetics and Euripides' Bacchae. Princeton, NJ.

Segal, C. 1993. Euripides and the Poetics of Sorrow: Art, Gender and Commemoration in Alcestis, Hippolytus and Hecuba. Durham, NC.

Svenbro, J. 1984. "La découpe du poème. Notes sur les origines sacrificielles de la poétique grecque." Poétique 58:215-232.

Tambiah, S. J. 1985. Culture, Thought, and Social Action: An Anthropological Perspective. Cambridge, MA.

TCL See Nagy 1994/1995a.

Vidal-Naquet, P. 1986. “The Black Hunter Revisited.” Proceedings of the Cambridge Philological Society 212:126-144.

West, M. L. 1971. “Stesichorus.” Classical Quarterly 21:302-14.

-- . 1985. The Hesiodic Catalogue of Women. Oxford.

-—-. 1999. “The Invention of Homer." Classical Quarterly 49:364-382.

--—. 2003. ed. and transl. Homeric Hymns, Apocrypha, Lives. Cambridge MA.

Wilamowitz-Moellendorff, U. von, ed. 1916. Reprinted 1929. Vitae Homeri et Hesiodi. Berlin. 
Winkler, J. J. 1990. “The Ephebes' Song: Tragöidia and Polis.” In Winkler and Zeitlin 1990. 20-62. Princeton, NJ. Original publication 1985 in Representations 11:26-62.

Winkler, J. J. and F. Zeitlin, eds. 1990. Nothing to Do with Dionysos? Athenian Drama in Its Social Context. Princeton, NJ.

Zeitlin, F. 1985. "The Power of Aphrodite: Eros and the Boundaries of the Self in the Hippolytus." In Directions in Euripidean Criticism, ed. P. Burian. 52-111 and 189-208. Durham, NC.

---. 1990. "Playing the Other: Theater, Theatricality, and the Other in Athenian Drama." In Winkler and Zeitlin 1990.63-96. Princeton, NJ. 